\title{
軟弱粘土地盤上の橋台の変形対策と その費用対効果に関する解析的検討
}

\author{
川井 俊介 1 ・稲垣 太浩 $2 \cdot$ 堀越 研一 1 板清 弘 $3 \cdot$ 三嶋 信雄 $4 \cdot$ 太田 秀樹 5
}

\author{
1正会員 大成建設株式会社 技術センター 土木技術研究所（干245-0051 神奈川県横浜市戸塚区名瀬町344-1） \\ E-mail: s-kawai@ce.taisei.co.jp \\ E-mail: hrkkni01@pub.taisei.co.jp \\ 2正会員 中日本高速道路株式会社 金沢支社（广920-0365 石川県金沢市神野町東170) \\ E-mail:m.inagaki.aa@c-nexco.co.jp \\ 3正会員 中日本高速道路株式会社 中央研究所（广194-8508 東京都町田市忠生1-4-1） \\ E-mail: h.takiyo.aa@c-nexco.co.jp \\ 4正会員 川崎地質株式会社 事業推進本部（一108-8337 東京都港区三田2-11-15） \\ E-mail: mishiman@kge.co.jp \\ 5フェロー会員 東京工業大学大学院 理工学研究科 国際開発工学専攻（†152-8552 東京都目黒区大岡山12-12-1） \\ E-mail: ohta@ide.titech.ac.jp
}

\begin{abstract}
厚い軟弱粘土地盤上に構築された実在の橋台およびその背面盛土を対象に, 変形対策工とその効果を解析的に検証 し，施工中から供用時の維持管理を含めた費用の観点から最適な対策工の検討を行った。同橋台は，厚さ60 mにもお よぶ軟弱粘土地盤上に構築され, 施工中から幾多の対策を施しながらも背面盛土の継続的な沈下が発生し, 供用開始 後13 年経過した時点で, 抜本的対策としてEPS（Expanded Poly-Styrol: 発泡スチロール）置換による盛土荷重軽減を 余儀なくされた. 同橋台に対して，1)EPS置換による荷重軽減時期が対策効果に及ぼす影響, および2) 近年, 適用事 例が増加している気泡混合軽量土 (FCB) による荷重軽減工法を適用した場合の対策効果 を解析的なパラメトリッ クスタディを通して検討し，実資料を基にした総対策費用と照らし合わせて効果的な対策工のあり方を検討した.
\end{abstract}

Key Words : abutment, soft clay, deformation, elasto visco plastic model, analysis, life cycle cost, performance

\section{1. はじめに}

構造物の設計基準を性能規定化するための検討が国内 外で活発となっている. 土構造物の設計に関しても例外 ではなく, 性能設計に向けての議論やしくみの構築が進 められているが，その方向性が完全に確立されたとは言 えない.この原因のひとつとして, 土構造物の設計精度 が多くの要因に依存することが挙げられる。これは，土 構造物が，鋼材やコンクリートなどの人工材料で構築さ れた構造物とは異なり, 以下の特異性を有していること に起因する.

(a) 鋼材などの高度に製造管理された工業製品の品質の ばらつきが極めて少ないのに対して，地盤は限られ た地盤調查結果から抽出された特性のみしか知るす べがなく, 土構造の性能に影響を及ぼす地盤全体を, そのばらつきを含めて把握するのは容易ではない．

(b) 鋼材などは, ひずみゲージなどにより，施工中や供 用中の応力状態を容易に把握することが可能である が，地盤内の応力状態は，最新の計測技術をもって しても難しい，すなわち，太田 ${ }^{1)}$ 指摘しているよう
に，土構造物のおかれた現在の姿を，設計で想定し た姿と比較し検証するのは容易ではない.

(c) 土構造物の場合, 強度や変形特性が時間的に大きく 変化する地盤材料に対して, 構造物の供用期間であ る数十年にも及ぶ時間軸での挙動を把握する必要が ある。

(d) 土構造物の場合, 設計や挙動予測に使用寸るモデル を限定することが難しく，しかも，その挙動を支配 するパラメータが拘束圧や時間などに依存している.

(e) 道路構造物では土工区間が圧倒的に多いため, すべ ての区間でその挙動を詳細に把握することは難しい. 実務的には，維持管理上問題となる区間を予め抽出 した上での事前対策が要求される.

文献2)によれば，性能設計とは, “明確に設定された構 造物の要求性能を満足させるために, 自由度の高い設計 を行うこと” と定義されている. 大きな沈下や変形が予 測される軟弱地盤上の道路構造物の場合, 供用期間中に 与えられた機能要件を満足するか否かを予測することは 重要な設計項目である. 観測施工による情報をもとに, 過去の挙動や現在の状況などを解析的に検討し, 長期挙 
動の予測精度を向上させるために地道な努力が営まれて (る33), (), .

図-1は, 観測施工を前提にした設計精度, 道路の機能, ならびに維持管理・対策費用の変化を模式的に示したも のである. 事前の調査ボーリングや室内土質試験の情報 が限られるなかで設計を余儀なくされる場合，その設計 は, 高い不確定性を有している. 建設開始に伴い観測施 工を行った場合, 計測結果に基づいた設計解析へのフィ ードバックにより設計精度が向上していく．供用開始後 も観測を継続した場合には，維持管理・対策を含めたそ の後の挙動に関する情報も蓄積され, 当該構造物の挙動 予測精度はさらに向上寸る. 一方, 供用開始からの道路 機能は徐々に低下していき, 道路機能を確保するための 維持管理・対策費用は増加していく. 建設前の設計精度 を向上させるために試験盛土などを実施して情報を蓄積 寸る方法3,5,5)向があるものの, 敷地条件や限られた期間, 予算の中ですべての箇所で対応できるとは限らない.

また, 軟弱地盤上の盛土の挙動を経時的に評価し, 構 造物の性能という観点から多様な対策工や維持補修の効 果を解析的に比較検証し, 当該構造物のライフサイクル コストを議論する試みは文献7), 文献8)によって報告さ れており，その有効性が検証されている。

本論文では，同様なアプローチを厚い軟弱粘土地盤上 に構築された橋台およびその背面盛土の変形問題に適用 し，有効な対策工を解析的なパラメトリックスタディを 通して検討寸るものである．同橋台は，北陸自動車道の 建設に際して構築されたものであり, 軟弱地盤の沈下や 変形に起因寸る長期にわたる維持管理期間を経た後に, 抜本的対策として背面盛土をEPS (Expanded Poly-Styrol : 発泡スチロール) に置換する荷重軽減対策が実施された. 本検討では, 当該構造物の実際の施工過程やその後の維 持管理・対策経緯を膨大な資料から詳細に調査し，これ らの経過を可能な限り考慮することとする. 併せてこれ らの対策に要した費用を過去の資料から調查し，対策効 果との関連性を検証する. 対策工や計測, 数值解析の技 術の進んだ現在において，“過去を顧みて’さまざまな対

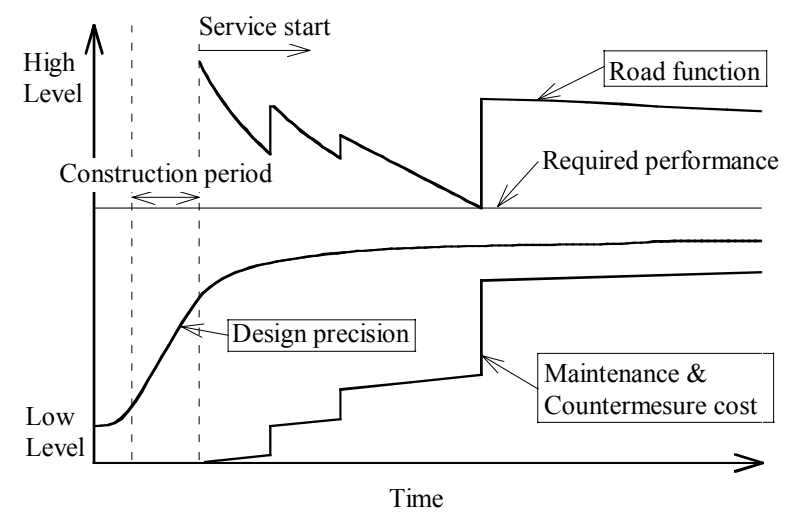

図-1 設計精度, 道路機能と対策費用の経時変化（模式図）
策の可能性を検証するものであり，軟弱地盤上の土構造 物を今後, 適切に維持管理するために有用な知見を提供 するものである.

同橋台が建設された地区では，数十年後の残留沈下量 や縦断線形, 構造物の変位量などを勘案し, 以下に示す 3 種類のレベルに応じた維持管理がなされている99.

(a) 管理レベル1 オーバーレイ(沈下分を補うための路 面高修正）を実施しない場合で，10年後においても 縦断線形が走行性を損なわない程度に確保できる区 間であり, 基本的に無対策で維持管理可能なレベル,

(b) 管理レベル2 10 年後までにオーバーレイ工事など による段差・縦断の修正により走行性が確保できる レベル,

(c) 管理レベル3 管理レベル2の区間の中で，オーバー レイが不可欠であるが，オーバーレイを実施すると 周辺地盤や構造物の変状が進行し大規模な構造物の 修繥や付替が必要となるレベル，この場合は30年後 の路面沈下量とそれに基づく構造物の変状や広域地 盤沈下の影響を考慮する.

本論文で扱う橋台の場合，厚い軟弱粘土地盤上に構築 された盛士沈下を効果的に抑制する方策が建設当時なか ったことに起因して, 当初, 管理レベル2に相当する維持 管理がなされていた. しかしながら，想定以上の沈下が 継続し, 隣接田面の機能復旧などを行ってきたものの, 道路機能が損なわれることが予測されたため，管理レベ ル3に分類される抜本的対策を実施することとなった. 建 設当時は, 詳細な解析や荷重軽減対策の採用は一般的で はなく，いわば技術の進展がこのような対策を可能とし たものである.

本論文では，上記，実在橋台ならびにその背面盛土を 含む縱断面有限要素解析を通して, 以下の検討を行うも のである.

(a) 荷重軽減時期が対策効果に及ぼす影響

EPSによる背面盛土の荷重軽減は, 供用開始から約 13 年経過した時点で実施された。この対策の実施時期 を変化させた場合の対策効果とコストとの関係を検 討する.

（b）気泡混合軽量土（FCB）を使用した場合の対策効果 EPSによる荷重軽減が実施された時点では, 比較対象 となっていなかったFCBの適用性を解析的に検討す る. FCBは, EPSと比較して, 単位体積重量が大きく 荷重軽減効果は小さい反面, 経済性に優れており, これを用いた荷重軽減を早期に実施した場合の対策 効果を検討する. なお，同橋台背面盛土の沈下対策 経緯, 近傍の盛土の沈下現象とEPSによる荷重軽減効 果に着目した横断面解析と動態観測結果については, 文献10)，11)，12)に詳細に示されている. 


\section{2. 検討対象橋台の概要}

本論文では，北陸自動車道 五貫野高架橋A2橋台とそ の背面盛土を検討対象とする. 同高架橋は，北陸自動車 道の上越インターチェンジと柿崎インターチェンジの間 に位置するが，建設された保倉川地区は，路線全体の中 でも, 最も高塑性な粘性土が厚く分布する地域であり,

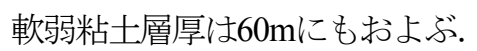

五貫野高架橋の路面高はこの地区で最も高く，かつ高 架橋部分での沈下が杭基礎で抑制されているため, 背面 盛土部との段差が生じやすく, 路面修正が必要な要因と なっている.

五貫野高架橋A2橋台は，1980年に建設が開始され，後 述の幾多の対策を実施した後, 1983年から供用が開始さ れた．供用開始後も，路面沈下による段差や縦断線形の 修正，橋台の側方移動による支承や伸縮継手の補修，2 連Boxカルバート（A3橋台）の沈下に伴う排水対策，な らびに周辺の地盤沈下に起因する田面復旧などの維持管 理を継続してきた.

しかしながら，橋台背面盛土の継続的沈下が予想以上 に大きく, 橋台が沈下を伴いながら背面側に回転し, 主 桁が凸型に変形したため, これ以上変形が進行すると,
設計時に予期していなかった応力が発生することが推測 された. これまでの維持管理だけでは周辺への影響が避 けられず，さらには将来的に道路機能まで損なわれると 判断されたため, 1996年から1997年にかけて，抜本的な 対策として背面盛土をEPSに置き換える荷重軽減対策が 実施された.

EPSによる置換厚さは, 沈下量の動態観測結果, 軟弱 粘土の圧密降伏応力, および除荷長期圧密試験結果をも とに決定された ${ }^{9)}$. 除荷長期圧密試験では, 現地で採取 した不擋乱試料に圧密降伏応力に相当寸る圧密荷重を作 用させ，任意の除荷率で荷重を低減させた。 その結果, 盛土荷重の30\%を除荷すれば，その後の沈下はほぼなく なり, 大規模な補修は必要ないと判断された。荷重軽減

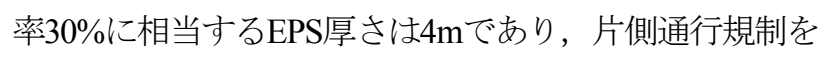
行いながら2回に分けて施工した。

\section{（1） 高架橋建設地点の地盤状況}

高架橋建設地点での土層構成および基本物性をそれぞ れ図-2, 図-3に示寸. 図-2に示寸ように, 地下水位は標 高4 $5 \mathrm{~m}$ 付近に位置し, 盛土前の地表面の標高と等しい. 図-3においてEPS置換による対策部の地盤調査位置はA2 橋台背面から新潟側へ約 $34 \mathrm{~m}$ （路線キロポスト KP

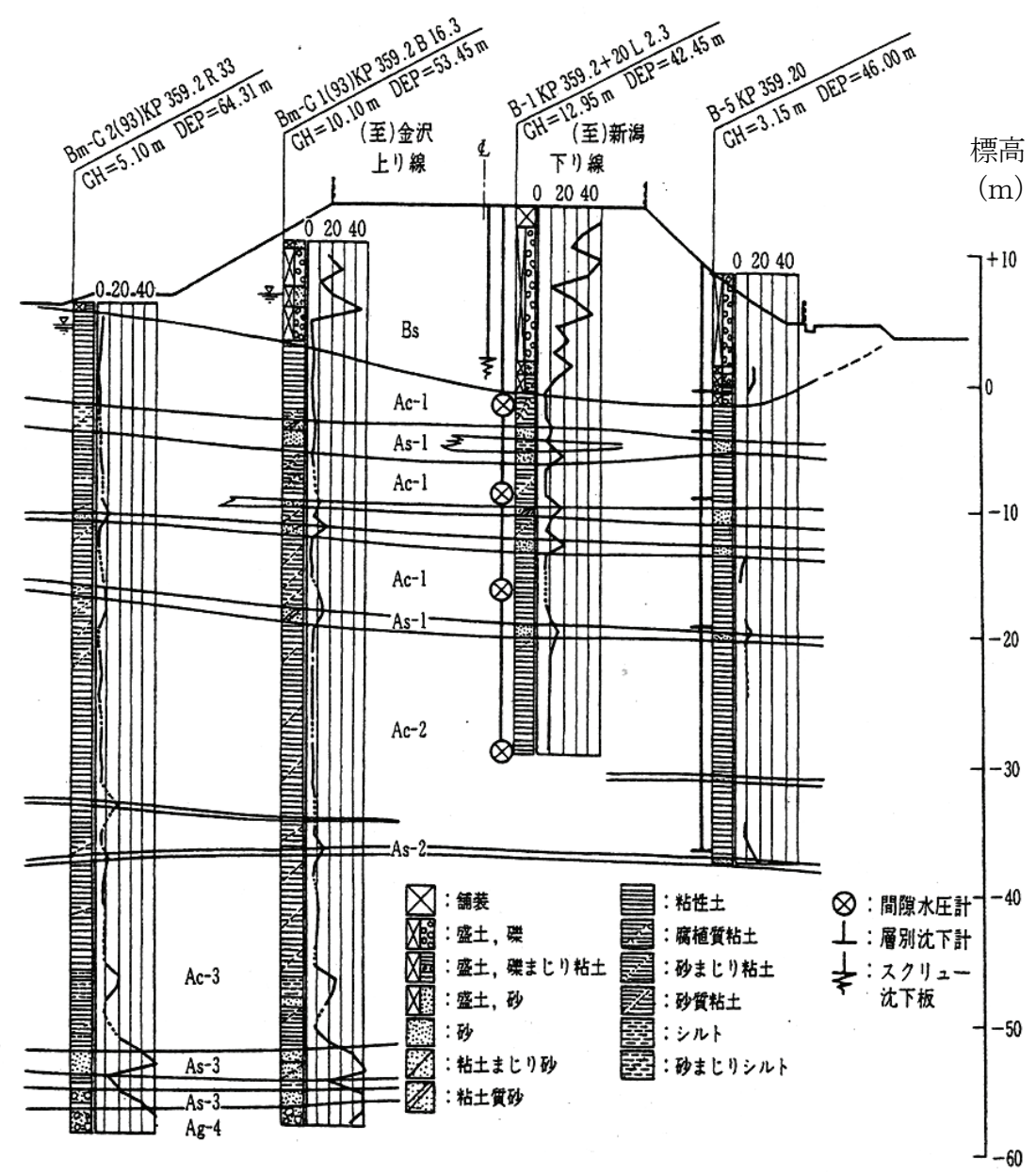

図-2 橋台背面盛土部 横断面地盤状況（路線キロポストKP 359.2 付近） ${ }^{10), 13)}$ 

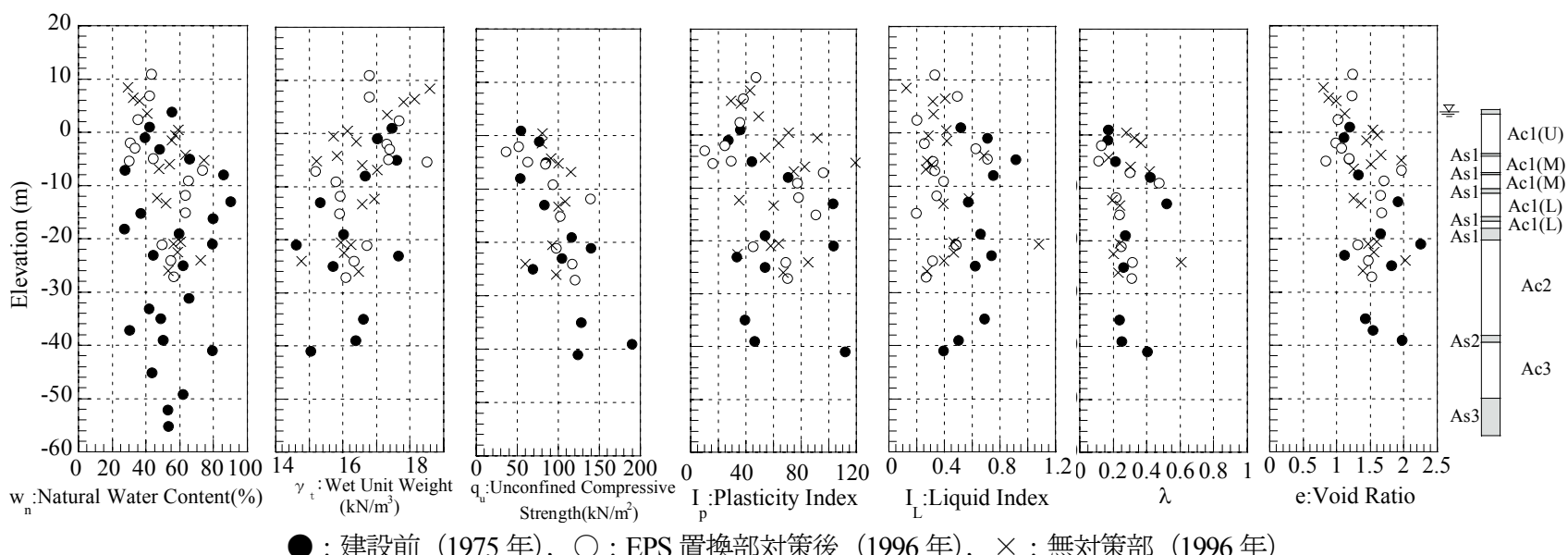

- : 建設前（1975 年），○：EPS 置換部対策後（1996 年)，×：無対策部（1996 年）

図-3 高架橋建設前および EPS による荷重軽減後の地盤物性

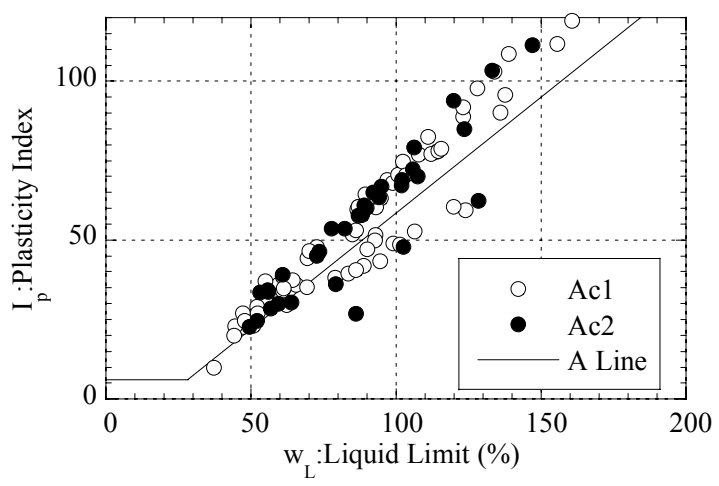

図-4＼cjkstart高架橋建設地点における粘性土の塑性図

to Kanazawa

to Niigata

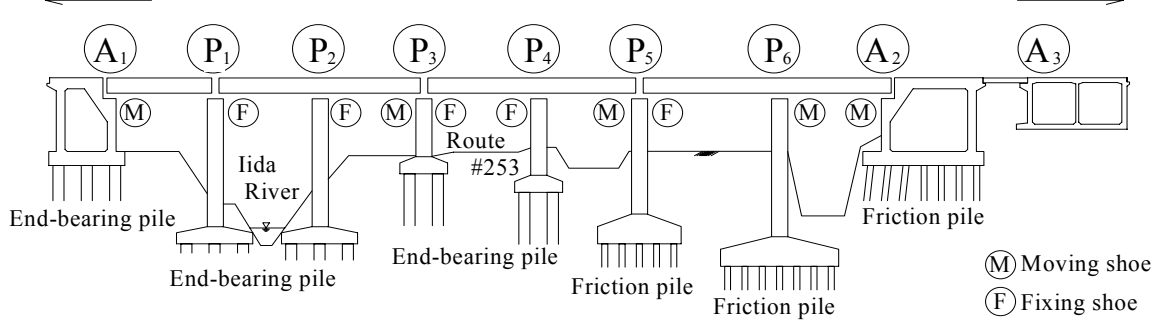

図-5＼cjkstart五貫野高架橋を構成する橋台と橋脚（文献9）を加筆修正）

359.2）付近，無対策部分は，さらに新潟側に $200 \mathrm{~m}$ 行っ たKP 359.0付近（図-6参照）となっている. これらの図 によれば，建設後の時間の経過につれて自然含水比や密 度などの物理特性や一軸圧縮強さなどの強度特性のばら つきがわずかに小さくなる傾向，およびAc1層で圧縮指 数入がやや高い傾向などを読み取ることができる.

五貫野地区における沖積粘土層（Ac1層，Ac2層）の塑 性図を図-4に示した。当該地点の粘性土は，A線よりも 上にプロットされるものが多く, 土質分類上CH（高塑性 粘土）に属する.

\section{（2）高架橋の設計，施工経緯}

五貫野高架橋は，保倉川と下流で合流する飯田川およ び国道253号線を跨ぐ全長205.1mの高架橋である. 図-5
に示すように，A1，A2橋台に加えて，P1〜P6の6基の橋 脚を有している.このうち，A1橋台，P1〜P4橋脚は，直 径 $1.5 \mathrm{~m}$ の場所打ちコンクリート杭による先端支持杭，P5, P6橋脚ならびにA2橋台は, 直径0.8mの鋼管杭による摩擦 杭で支持されている. A1橋台〜P4橋脚間の構造形式は, 設計の見直しが行われ，基礎杭形式を摩擦杭から先端支 持杭に変更している．この経緯は不明であるが，P3〜P4 橋脚間の高架橋下を通過する国道253号線の車両制限領 域確保のため，沈下の小さい先端支持杭を適用したもの と推察される.

また, 高架橋へのすりつけ部分は盛土形式となるため, プレロード盛土によって粘土地盤の強度を増加させた後, 橋台ならびに本体盛土を構築する予定であった，プレロ 一ド盛土に先立ち，橋台前面に向かうすべりに対する安 
定性を確保寸るため, 前面法尻部に鋼矢板 (II型, $\mathrm{L}=9.5 \mathrm{~m}$ ) を打設した（図-6)。しかしながら，プレロード盛土高さ が $7 \mathrm{~m}$ （計画高 9～10m） となった時点て鋼矢板の水平変 位量が増大したため，プレロード盛土を中止した．すな わち，プレロード盛土を当初予定高さまで施工すること ができなかった.

その後, 本体盛土構築時の安定性を向上させる方策と して, 図-6に示寸砂利杭を橋台基礎杭背面に設置した後, 橋台本体および背面盛土を構築して 1982 年 10 月に工事 を終了した．しかしながら，その後，1983 年 5 月まで橋 台の動態観測を行った結果, A2 橋台で 90〜180 mm の沈 下と背面側への 30〜 40mm に及ぶ側方変位が確認された ため，橋台背面盛土を撤去し，アプローチクッション方 式の A3 橋台（2連 Box カルバート） および A3 橋台と

表-1＼cjkstart五貫野高架橋の施工過程

\begin{tabular}{|c|c|l|}
\hline 1 & 鋼矢板設置 & $(1980.11)$ \\
\hline 2 & プレロード & $1980.11 \sim$ \\
\hline 3 & 放置期間 & $1981.7 \sim 11$ \\
\hline 4 & 除荷 & 1981.11 \\
\hline 5 & 鋼管杭打設 & $(1982.3)$ \\
\hline 6 & 砂利杭打設 & $1982.4 \sim 5$ \\
\hline 7 & A2橋台設置 & $1982.4 \sim 8$ \\
\hline 8 & 背面盛土構築 & $1982.5 \sim$ \\
\hline 9 & 背面盛士除去 & $(1983.7)$ \\
\hline 10 & A3橋台設置 & $(1983.7)$ \\
\hline 11 & 供用開始 & 1983.11 .9 \\
\hline 12 & オーバーレイ & $(1985.3,1985.7,1987.9)$ \\
\hline 13 & EPS置換 & $\begin{array}{l}1996.4 \sim 1997.3 ~ \\
\text { 新潟方面車線 } \\
1997.4 \sim 1998.3 \text { 金沢方面車線 }\end{array}$ \\
\hline
\end{tabular}

()内は想定值

to Niigata

$110 \mathrm{~m}$ (Section Replaced by EPS)

Observation point Replaced by EPS

Gokanno

A3 box type culvert

Bridge A2 abutment
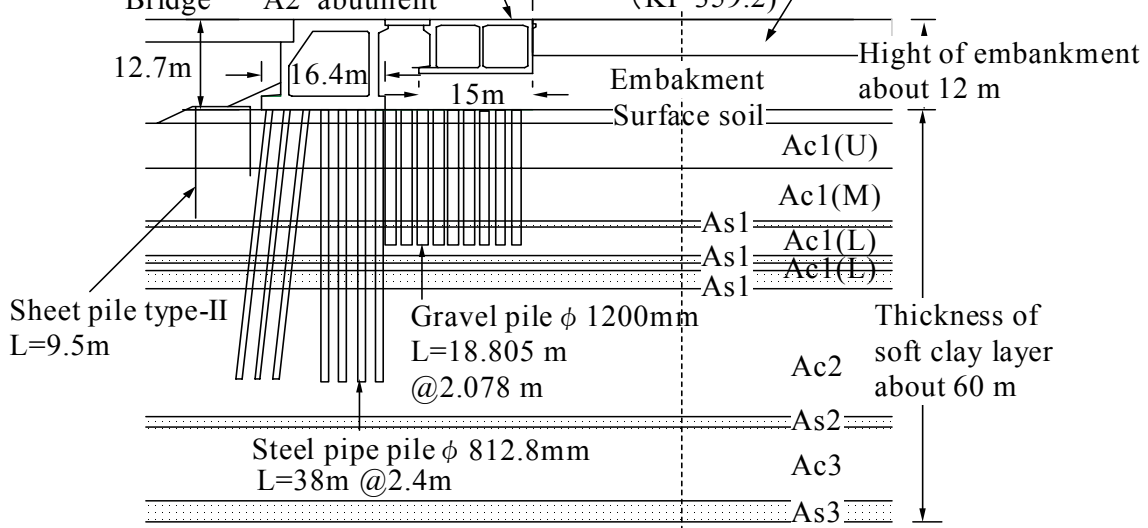

図-6 五貫野高架橋 A2 橋台の構造概要

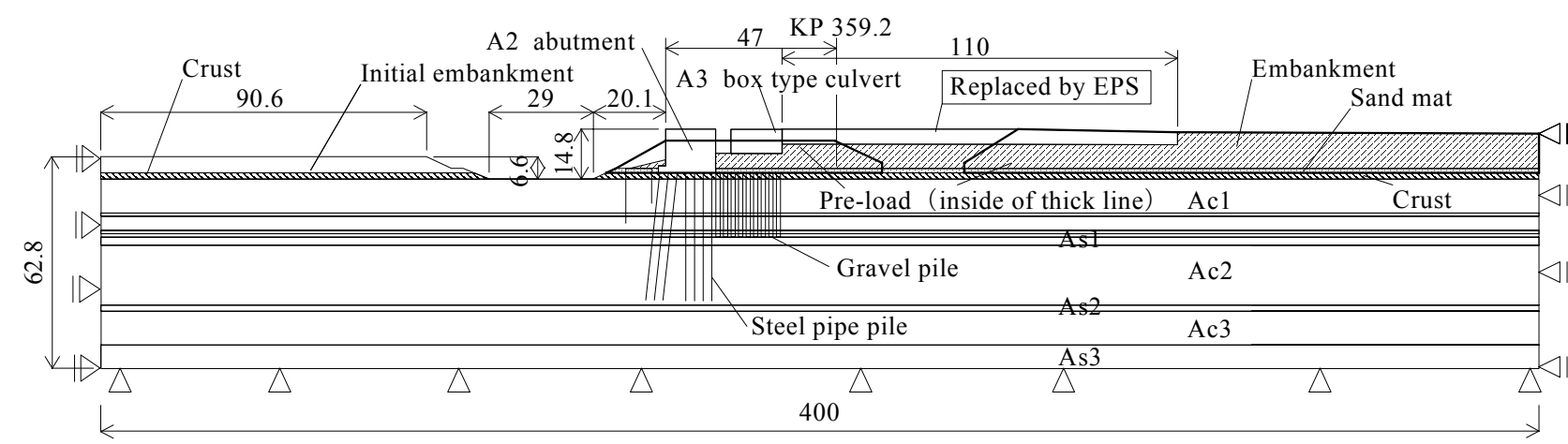

図-7 解析モデル（五貫野高架橋 $\mathrm{A} 2$ 橋台）

(m)

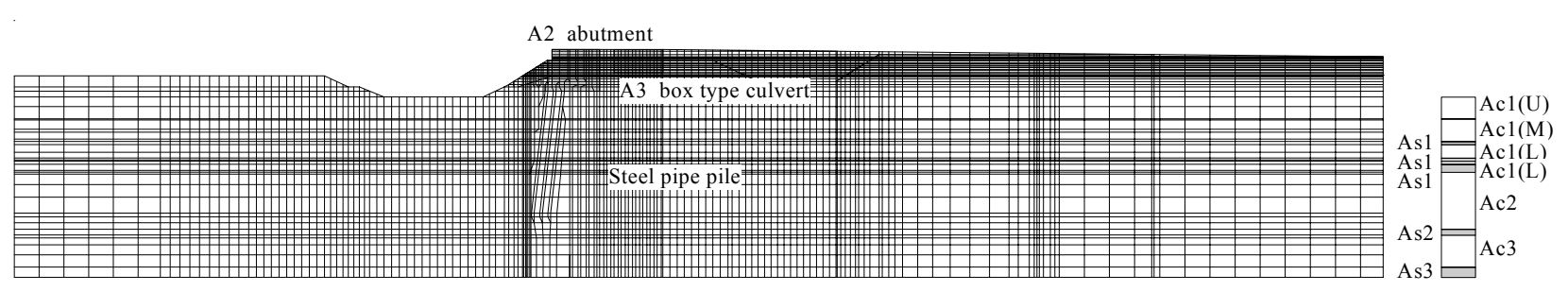

図-8 解析で用いた要素分割（五貫野高架橋 A2 橋台） 
表-2 解析パラメータ一覧 (Case 1)

\begin{tabular}{|c|c|c|c|c|c|c|c|c|c|c|c|c|c|c|}
\hline 地 層 & $\begin{array}{c}\text { 層厚 } \\
\text { m }\end{array}$ & モデル & $\begin{array}{c}\text { 単位体 } \\
\text { 積重量 } \\
\gamma_{\mathrm{t}} \\
\mathrm{kN} / \mathrm{m}^{3}\end{array}$ & $\begin{array}{c}\text { せん断弾 } \\
\text { 性係数 } \\
\mathrm{G} \\
\mathrm{kN} / \mathrm{m}^{2}\end{array}$ & $\begin{array}{c}\text { ポアリ } \\
\text { 比 } \\
v^{\prime}\end{array}$ & \begin{tabular}{|c|} 
先行時 \\
静止土圧 \\
係数 \\
$K_{o}$ \\
\end{tabular} & $\begin{array}{c}\text { 透水係数 } \\
k \\
\mathrm{~cm} / \mathrm{s}\end{array}$ & \begin{tabular}{|c|} 
初期 \\
間隙比 \\
$e_{i}$
\end{tabular} & $\begin{array}{c}\text { 压縮 } \\
\text { 指数 } \\
\lambda\end{array}$ & $\begin{array}{c}\text { 膨潤 } \\
\text { 指数 } \\
\kappa\end{array}$ & $\begin{array}{l}\text { 過圧 } \\
\text { 密比 } \\
\text { OCR }\end{array}$ & $\begin{array}{c}\text { 限界状 } \\
\text { 態応力 } \\
\text { 比 } \\
M\end{array}$ & $\begin{array}{c}\text { 二次圧縮 } \\
\text { 指数 } \\
\alpha\end{array}$ & \begin{tabular}{|c} 
初期体積 \\
ひずみ速度 \\
$\dot{v}_{o}$ \\
$1 /$ day
\end{tabular} \\
\hline 盛土 & & & 17.66 & 11039 & 0.330 & $\begin{array}{l}0.49 \\
\end{array}$ & $1.00 \mathrm{E}-03$ & & & & & & & \\
\hline クラストト & 1.80 & 弹性体 & 17.66 & 5889 & 30 & 0.49 & & & & & & & & \\
\hline Ac1（U) & 6.80 & & 16.68 & & 0.374 & 0.60 & 8.871 & 1.284 & 0.201 & 0.020 & 3.2 & 1.113 & & $4.22 \mathrm{E}-07$ \\
\hline $\operatorname{Ac} 1(\mathrm{M})$ 上 & 4.20 & 弾粘塑性体 & 16.91 & & 0.390 & 0.64 & $9.51 \mathrm{E}-08$ & 1.510 & 0.270 & 27 & 1.7 & 1.113 & & \begin{tabular}{|c|}
$5.17 \mathrm{E}-07$ \\
\end{tabular} \\
\hline $\operatorname{Ac1}(\mathrm{M})$ 下 & 2.85 & & 16.23 & & & 0.75 & & & 0.3 & & 1.2 & 1.113 & & 7E-07 \\
\hline As1 & 0.95 & 弾性体 & 17.66 & 27599 & 330 & 0.49 & & & & & & & & \\
\hline $\operatorname{Ac1}(\mathrm{L})$ & 4.20 & 弾粘塑性体 & 15.95 & & 32 & 0.76 & & 1.812 & 0.371 & 0.037 & 1.2 & 1.113 & & $6.33 \mathrm{E}-07$ \\
\hline As1 & 1.00 & 弾性体 & 17.66 & 11039 & 330 & 0.49 & $1.00 \mathrm{E}-03$ & & & & & & & \\
\hline $\operatorname{Acl}(\mathrm{L})$ & 1.00 & 弾粘塑性体 & 15.95 & & 0.431 & 0.76 & $6.72 \mathrm{E}-08$ & 1.616 & 0.327 & 0.033 & 1.2 & 1.113 & & $.00 \mathrm{E}-07$ \\
\hline As1 & 2.40 & 弾性体 & 17.66 & 18766 & & 0.49 & & & & & & & & \\
\hline Ac2 上 & 7.80 & & 16.02 & & & 0.63 & $5.84 \mathrm{E}$ & & & & & & & E-07 \\
\hline Ac2 下 & 10.00 & ו & 16.29 & & & 0.62 & 5.84 & 1.495 & .240 & 24 & 1. & 1.113 & & $2 \mathrm{E}-07$ \\
\hline As2 & 1.80 & 弾性体 & 17.66 & 20975 & 330 & 0.49 & $1.00 \mathrm{E}-03$ & & & & & & & \\
\hline Ac3 & 10.00 & 弾粘塑性体 & 16.29 & & 391 & 0.64 & $3.36 \mathrm{E}-08$ & 1.495 & 0.296 & 0.030 & 1.0 & 1.113 & $4.62 \mathrm{E}-03$ & 4.62E-07 \\
\hline As3 & 3.20 & 弾性体 & 17.66 & 20975 & 0.330 & 0.49 & $1.00 \mathrm{E}-03$ & & & & & & & \\
\hline
\end{tabular}

A2 橋台間の鉄筋コンクリート床版橋を施工した.

表-1は，同高架橋の施工過程を示したものである．後 述の数值解析では，複雑な施工過程を可能な限り忠実に 反映させた．なお，施工順序については既往の資料から 明らかとなったが，具体的な施工時期については不明な ものもあり，解析上は前後の工程時期から想定した。

\section{3. 解析モデル}

\section{（1）基本方針}

本検討では，橋台断面を含む縦断面に対して，2 次元 平面ひずみ問題としてモデル化した．解析モデル，およ び要素分割をそれぞれ図-7, 図-8 に示す。側方境界まで の距離として, 橋台前面側に地盤モデル厚さの約 2 倍, 背面側に約 3 倍の距離を設定した．実際の盛士構造物の 挙動は 3 次元的であり, 路線軸直行方向への地盤の変形 に起因する盛土の沈下挙動は，本検討では考慮されてい ない. 3 次元変形問題としてモデル化する有用性は否め ないものの, 以下の理由から, 2 次元平面ひずみ問題と して取り扱うこととした。

1) 本検討の主目的は, 実際の橋台挙動を解析的に緻密に 再現するのではなく, 比較解析を通して対策工の有効 性を議論するものであり, 平面ひずみ条件の解析でも， 対策工の有効性の比較検討が可能であると判断され た.

2) 本検討の対象とした橋台および背面盛土は極めて複 雑な施工過程, ならびに矢板, 鋼管, 砂利杭といった 多様な工種, 材料から成り立っており，これらを忠実 に 3 次元的にモデル化することは, 実務設計への適用 を考えても現実的ではない.

解析の際の地盤パラメータは，事前の地盤調査結果， 或いは設計で想定された值を最大限活用するものとし，
KP 359.2 付近でのボーリング調査結果（図-3）をもとに 水平成層地盤を想定した。 その後，地表面沈下の動態観 測結果とのフィッティング解析を実施した結果，解析に 用いる透水係数を標準圧密試験から得られた值の 10 倍 にすると両者の整合がほぼ得られたため，これを基本ケ 一スとして対策工効果に対するパラメトリックスタディ を行った ${ }^{14), 15)}$. 大きめの透水係数を設定すると実測值と の整合性が得られる傾向は，文献 16)，17)，18)にも述心 られており, 透水係数の異方性や薄い砂層が介在してい た可能性は否めないものの, 原因の特定はされていない.

また, 実際の地表面形状を解析に反映させるため，A2 橋台前面にも高さ $6.6 \mathrm{~m}$ の盛士をモデル化した（図-7). 解析上は, 表-1 に示した一連の施工過程の前にこの部分 の盛土載荷を行い，下部粘土地盤中の過剰間隙水圧の消 散が確認された後, 一連の橋台施工をモデル化している.

\section{（2） 解析パラメータの設定}

本論文では，粘性土地盤に対しては，関口・太田によ る弾粘塑性モデル ${ }^{19}$ を適用した。 その他の材料，すなわ ち, 砂層, 盛土, サンドマット, 砂利杭, 橋台などの構 造物は線形弾性体と仮定し，杭基礎は線形梁要素で表現 した. 解析で使用したパラメータを表-2に示す.

粘性土層（Ac1，Ac2，Ac3 層）…関口・太田による弾粘 塑性モデルを適用した。限界状態応力比 $M$ は, 当該地点 における三軸試験結果が限られていることから，便宜的 な值として有効内部摩擦角( $\phi$ ')を $28^{\circ}$ として算出した. その他，解析に必要な物性は表-3 に示す通りである. 初 期体積ひずみ速度は，90\% 圧密に要する期間をもとに $t_{\mathrm{c}}$ を設定した。 その際，当該地点の粘性土の圧密係数(約 40〜400 $\mathrm{cm}^{2} / \mathrm{d}$ ), および最も厚い AC2 層の排水距離を念 頭に概略值として一律 $t_{\mathrm{c}}=10,000$ 日を設定した.

砂層（As1 層, As2 層) : 線形弾性体…標準貫入試験の $N$ 值をもとに表-2に示守物性とした.

盛土 : 線形弾性体…盛土の構築は盛土に相当する要素の 
表-3 解析定数の設定（関口・太田による弾粘塑性モデル）

\begin{tabular}{|c|c|}
\hline パラメータ & 設定方法, 参考文献 \\
\hline $\begin{array}{l}\text { 圧縮指数 } \lambda \\
\text { 膨張指数 } \kappa\end{array}$ & $\begin{array}{l}\lambda=0.434 C_{c} \\
\kappa=1 / 10 \lambda\end{array}$ \\
\hline 限界状態応力比 $M$ & $\begin{aligned} \phi^{\prime} & =28^{\circ} \text { とし, } \\
M & =6 \sin \phi^{\prime} /\left(3-\sin \phi^{\prime}\right)\end{aligned}$ \\
\hline 静止土圧係数 $K_{0}$ & $\begin{array}{l}K_{0}=0.44+0.42 \times 10^{-2} P I \\
\left(\text { Massarsch }^{20)}, 1979\right)\end{array}$ \\
\hline $\begin{array}{l}\text { 過圧密領域での } \\
\text { 土圧係数 } K_{i}\end{array}$ & $\begin{array}{l}K_{i}=K_{o}(\mathrm{OCR})^{0.54 \exp (-P / / 122)} \\
\left(\mathrm{Alpan}^{21)}, 1967\right)\end{array}$ \\
\hline ポアソン比 $v^{\prime}$ & $v^{\prime}=K_{0} /\left(1+K_{0}\right)$ \\
\hline ダイレタンシー係数 $D$ & $D=(\lambda-\kappa) / M\left(1+e_{o}\right)$ \\
\hline 二次圧縮指数 $\alpha$ & $\alpha=\alpha_{\mathrm{e}} /\left(1+e_{o}\right), \quad \alpha_{\mathrm{e}}=\Delta e / \Delta \log _{\mathrm{e}} t$ \\
\hline 初期体積ひずみ速度 $\dot{v}_{0}$ & $\dot{v}_{0}=\alpha / t_{c} \quad\left(t_{\mathrm{c}}=10,000\right.$ 日を設定 $)$ \\
\hline 透水係数 $k$ & $\begin{array}{l}\text { 標準圧密試験の結果から設定 } \\
\text { 応力変化による透水係数の } \\
\text { 変化は考慮しない }\end{array}$ \\
\hline
\end{tabular}

積み重ね，除荷は当該要素を除去することにより表現し た．厳密には，盛土の剛性も橋台全体挙動に影響を及ぼ すものと考えられるが，文献 7),8)での事例を参照し，か つ本検討の主目的が対策工の比較検討であることに鑑み， 弾性体でモデル化した.

クラスト: 線形弾性体...解析対象地域は水田が多いこと から, 地表面にクラストが存在している. 本解析では,

表-2に示す物性值を仮定した。

コンクリート構造物（A2 橋台，A3 橋台）: 線形弾性体... 単位体積重量が実際の構造物と等価になるように設定し た. ポアソン比はコンクリートに対する一般的な值(0.16) を用いるものとし，さらに，単位奥行き当りの上部工反 力を $\mathrm{A} 2$ 橋台, $\mathrm{A} 3$ 橋台に作用させている.

砂利杭 : 線形弾性体...弾性係数は， $\phi=35^{\circ}$ を道路橋示 方書 下部構造編に規定された関係 $\phi=15+\sqrt{15 N}$ に代 入して得られた $N$ 值から $E=2800 N$ 值 $\left(\mathrm{kN} / \mathrm{m}^{2}\right)$ より求め た. ポアソン比は 0.44 とした.

EPS : 線形弾性体…文献 22)を参照し, 単位体積重量 $0.196 \mathrm{kN} / \mathrm{m}^{3}$, ポアソン比は 0.11 , 弾性係数は, $5,886 \mathrm{kN} / \mathrm{m}^{2}$ とした.

鋼矢板, タイロッド: 線形梁要素...断面積, 断面 2 次モ ーメントを単位奥行き当たりの值に換算した.

鋼管杭:線形梁要素..鋼管杭は, 直径 $812.8 \mathrm{~mm}$, 板厚 $9 \mathrm{~mm}$ および $12 \mathrm{~mm}$ であり, 橋軸直角方向の杭間隔は $2.56 \mathrm{~m}$ で ある. 断面積, 断面 2 次モーメントを単位奥行き当りの 值に換算した。それ以上の奥行き方向の影響範囲は考慮 していない.
表-4 解析ケース

\begin{tabular}{|c|l|}
\hline Case & \multicolumn{1}{|c|}{ 解 析 条 件 } \\
\hline \hline Case 1 & $\begin{array}{l}\text { 事前の土質試験結果を基に事前予測の観点から } \\
\text { 解析パラメータを設定. 実施工過程をもとに解析. }\end{array}$ \\
\hline Case 2 & $\begin{array}{l}\text { 動態観測結果との整合を目的とし, Case 1 におけ } \\
\text { る粘土地盤の透水係数を } 10 \text { 倍にしてフィッティ } \\
\text { ングさせたもの. }\end{array}$ \\
\hline Case 3 & $\begin{array}{l}\text { Case 2 を基本に, A3 橋台を構築直後の供用開始 } \\
\text { 前に EPS による荷重軽減を実施した場合を想定. }\end{array}$ \\
\hline Case 4 & $\begin{array}{l}\text { Case 2 を基本に, EPS による荷重軽減を実施せず } \\
\text { にオー゙ーレイのみによって沈下に対処した場 } \\
\text { 合を想定. }\end{array}$ \\
\hline Case 5 & $\begin{array}{l}\text { Case 2 を基本に, A2 橋台構築直後に最初から EPS } \\
\text { による背面盛土を構築した場合を想定. }\end{array}$ \\
\hline
\end{tabular}

表-5 オーバーレイ回数と実施時期

\begin{tabular}{|c|c|c|c|c|c|c|}
\hline \multirow{2}{*}{ Case } & \multirow{2}{*}{$\begin{array}{l}\text { オーバ } \\
\text { ーレイ } \\
\text { 回数 }\end{array}$} & \multicolumn{5}{|c|}{ 実施時期 } \\
\hline & & 1 回目 & 2 回目 & 3 回目 & 4 回目 & 5 回目 \\
\hline 1 & 3 & \multirow{5}{*}{1985.3} & \multirow{2}{*}{1985.7} & \multirow{2}{*}{1987.9} & & \\
\hline 2 & 3 & & & & & \\
\hline 3 & 1 & & & & & \\
\hline 4 & 5 & & \multirow{2}{*}{1985.7} & \multirow{2}{*}{1987.9} & \multirow{2}{*}{1996.9} & \multirow{2}{*}{2002.10} \\
\hline 5 & 5 & & & & & \\
\hline
\end{tabular}

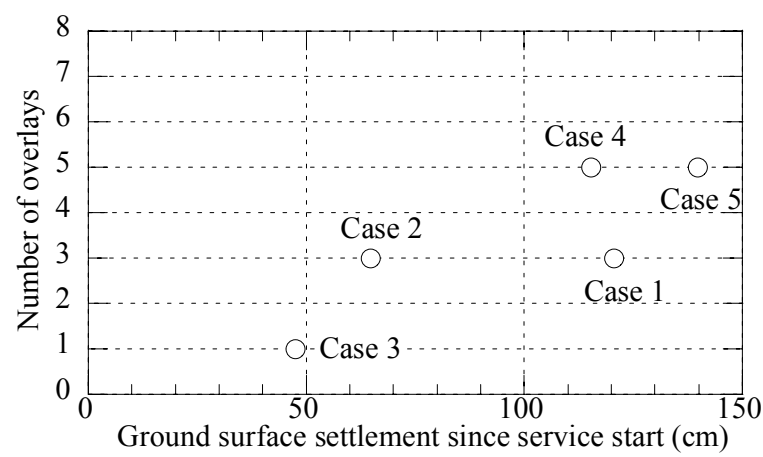

図-9 オーバーレイ回数と供用開始からの地表面沈下量

\section{4. 荷重軽減時期が対策効果に及ぼす影響}

\section{(1) 解析ケース}

実際には，供用開始から 13 年後に実施された EPS に よる荷重軽減時期が，橋台変位や周辺地盤の変位の抑制 といった対策効果に及ぼす影響を把握することを目的と して表-4に示すパラメトリックスタディを行った.

Case 2 が動態観測結果と整合させた基本ケースであり， 以後の比較解析のベースとなるものである. Case 3〜5 は, Case 2 で使用した解析パラメータや荷重軽減範囲を 同一条件としながら，EPSによる荷重軽減時期を変化さ せたものである. なお，Case 2 の EPS 置換は，道路供用 中であったため, 上下線 2 回に分けて実施しているが, Case 3 およびCase 5 では，道路供用開始前であるので, すべての置換を一度に行うものとした．なお，解析期間 


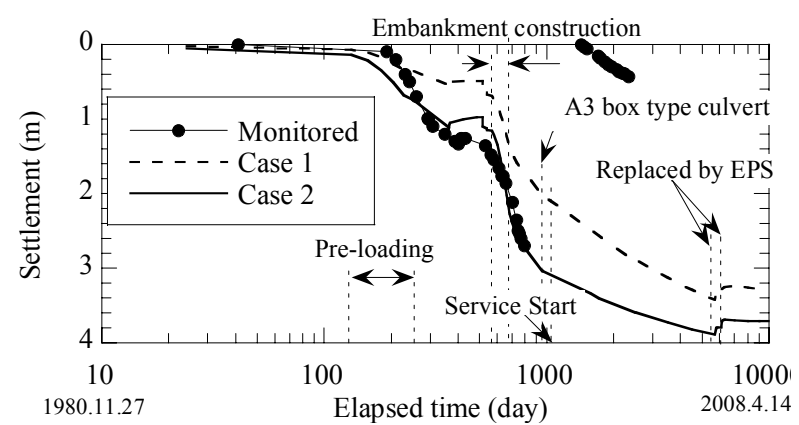

図-10 地表面沈下量の経時変化

(KP 359.2 地点 Case 1, Case 2)

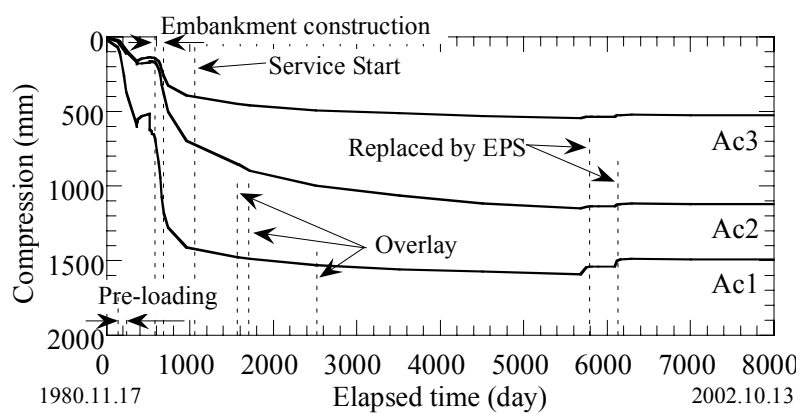

図-11 建設開始からの層別圧縮量の変化 (Case 2 解析結果)

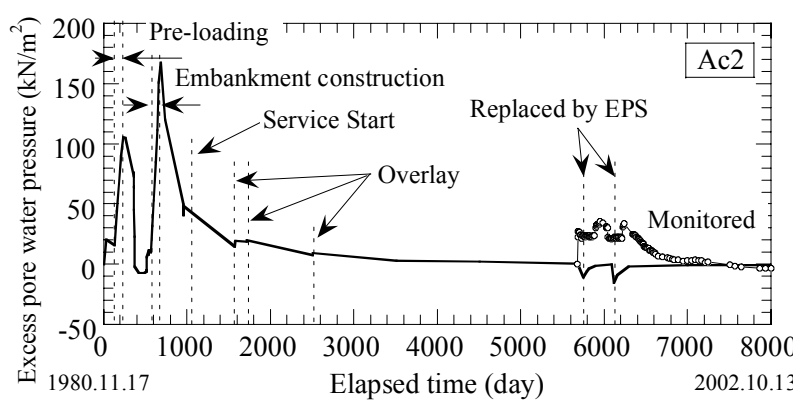

図-12 建設開始からの過利間隙水圧の変化 (Case 2 解析結果，動態観測結果，Ac2 層)

は供用開始から 44 年間(施工開始から 47 年間) とした。

また，解析では，供用開始後のオーバーレイ（沈下分 を補うための路面高修正）を考慮しており，Case 2 では 実際の補修記録より 3 回，その他のケースでは，事前に オーバーレイを考慮しない解析を一度行い，供用開始か らの地表面沈下量が $25 \mathrm{~cm}$ を超える毎に 1 回のオーバー レイを想定した解析を再度実施した（表-5)。想定したオ ーバーレイ回数と供用開始からの沈下量との関係を図 -9 に示す. オーバーレイ荷重は, オーバーレイ厚 $20 \mathrm{~cm}$ に 相当寸る等分布荷重を A2 橋台背面に作用させるものと した.

\section{(2) 解析結果}

\section{a）基本ケースと動態観測結果との比較}

Case 1 およびCase 2 で得られた橋台背面の地表面沈下 量と, これに対応寸る動態観測結果を図-10 に示寸. 当 然であるが，フィッティングを目的として行った Case 2

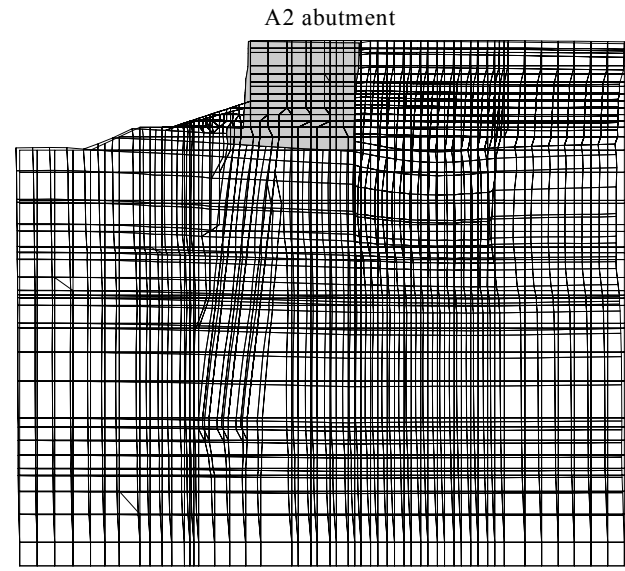

図-13 解析で得られた A2 橋台周辺地盤の変形モード (盛土完了時 : 建設開始から 678 日，Case 2)

では，観測結果にほぼ近い挙動となっている，なお，動 態観測結果で 1000 日付近の計測結果が不連続となって いるのは，計測が途中で中断されたためである．同図に よれば，建設開始から盛土完成時点で，約 $3 \mathrm{~m}$ の地表面 沈下が生じている.

図-11 は，建設開始からの各沖積粘性土層の圧縮量の 解析值を示したものである。この図によれば，粘土層の 中でも上部の Ac1 層の圧縮量が最も大きい. 層厚に対す る圧縮量の比率は, Ac1，Ac2，Ac3 の各層で各 12.5\%, 6.5\%，5.4\%となっており，圧縮ひずみの観点からも Ac1 層の圧縮が顕著である. 圧縮量の時間的変化に着目した 場合, Ac1 層, Ac3 層では建設開始から 2000 日程度で収 束している傾向があるが，Ac2 層では，より長期間にわ たっている. なお，すべての層において EPSによる荷重 軽減を行った際に僅かながらの隆起現象が認められる.

$\mathrm{Ac} 2$ 層に関して解析で得られた建設開始からの過剩間 隙水圧の推移と荷重軽減対策前からの過剩間隙水圧の動 態観測結果を図-12 に示寸．解析で得られた水圧值は, KP359.2 地点（図-7 参照）における各粘土層の中間深度 における值である．解析結果で供用開始前に過剩間隙水 圧が急激に減少しているのは $\mathrm{A} 3$ 橋台構築のための盛土 撤去を行ったためである. 盛土に伴い発生した過剩間隙 水圧は, 約 4,000 日経過時点でほぼ消散している. 解析 で得られた過剩間隙水圧変化は，観測結果と良く合って いるとは言い難いが，荷重軽減時に水圧が一時的に減少 する現象が,解析と観測結果の双方に見られる.ただし， 解析結果では，過剩間隙水圧が負側に転じているが，動 態観測結果にはこの傾向は見られない.

盛土完了時点（建設開始から 678 日後）での橋台周辺 地盤の変形状況に関して解析結果を図-13 に示寸. 橋台 上部が背面側に倒れ込むモードで変形しており, 文献 11) に示された，五貫野高架橋に隣接する保倉高架橋の変形 モードと類似している. 


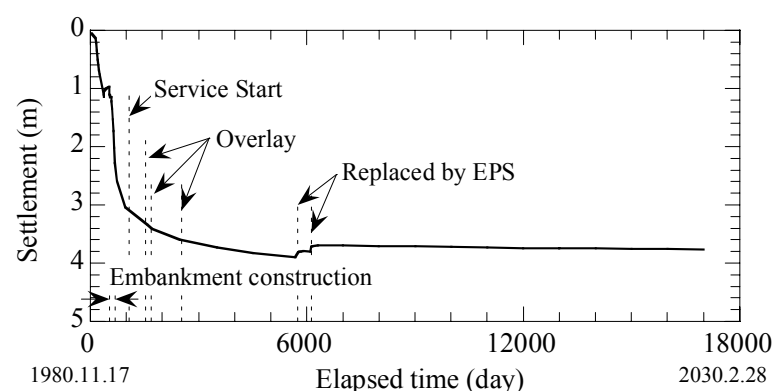

(a) 橋台背面の地表面沈下量（KP 359.2 付近）

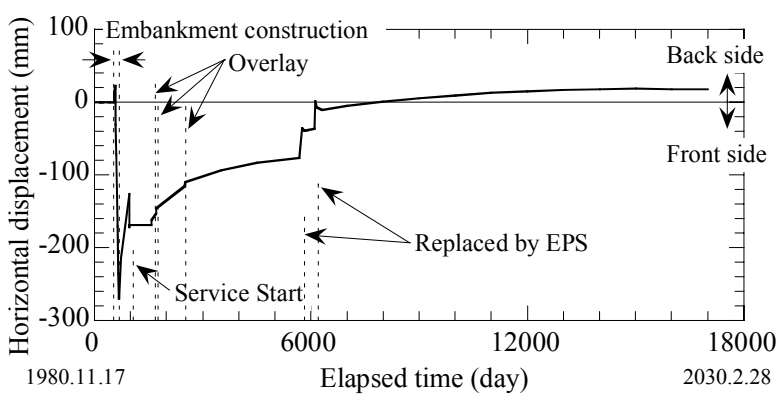

(b) 橋台上部側方移動量

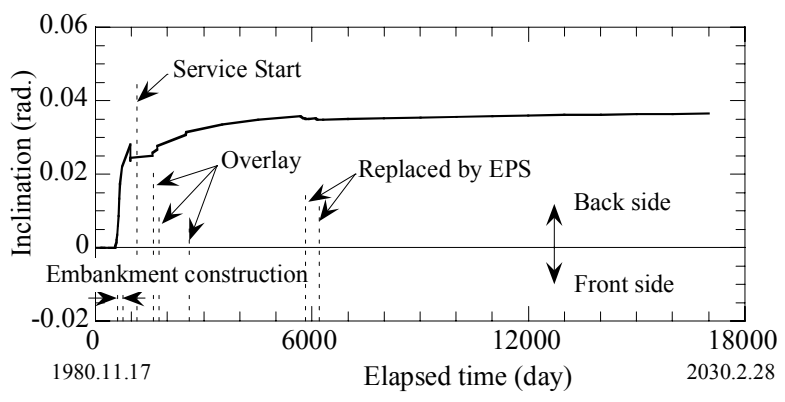

(c) 橋台回転量

図-14 橋台移動量と回転量の推移 (Case 2, 解析結果)

図-14 は, 橋台背面の地表面沈下量, 橋台上部側方移 動量および回転量の解析結果を示したものである. 背面 盛土の構築によって橋台が前面に押されるのと同時に, 盛土沈下による側方流動によって摩擦杭が前方に移動し, 橋台が背面側に回転している，沈下が収束すると橋台移 動と回転は収束する傾向にあることから，橋台の変位を 抑制するためには背面盛土の沈下を収束させることが有 効であることがわかる.

\section{b）荷重軽減時期を変化させた場合の挙動比較}

EPS による荷重軽減時期を変化させたケース（Case 3 ～5）を基本ケース（Case 2）と比較する.

解析で得られた橋台背面盛土の地表面沈下量を図-15 に示す. Case 3 は, A3 橋台設置直後に EPS 置換を行う 場合であり,それまでの挙動はCase 2 と同じである. Case 3 では, EPS 置換後の沈下速度は小さくなっているが,

Case 2 における EPS 置換後の沈下速度ほじは小さくない. Case 4 はEPSによる荷重軽減を実施しないケースであり， 沈下が継続している. Case 2 と比較すると EPS による荷 重軽減が有効であったことを示している. Case 5 は，A2

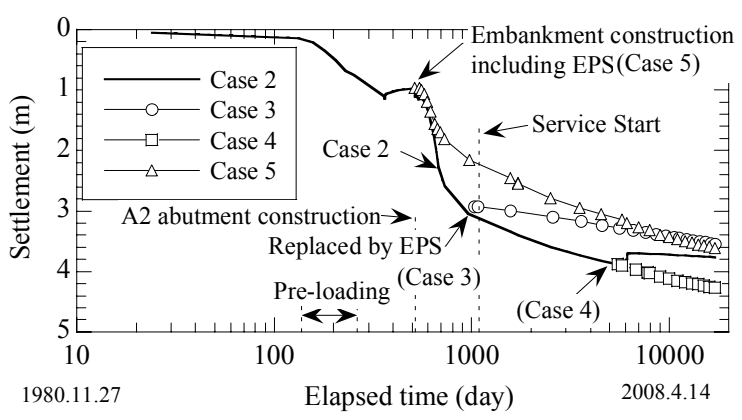

図-15 地表面沈下量の経時変化の比較

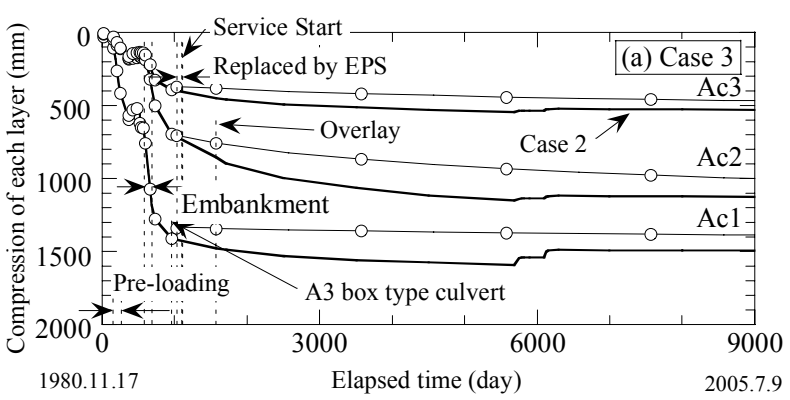

(a) Case 3 と基本ケース（Case 2）との比較

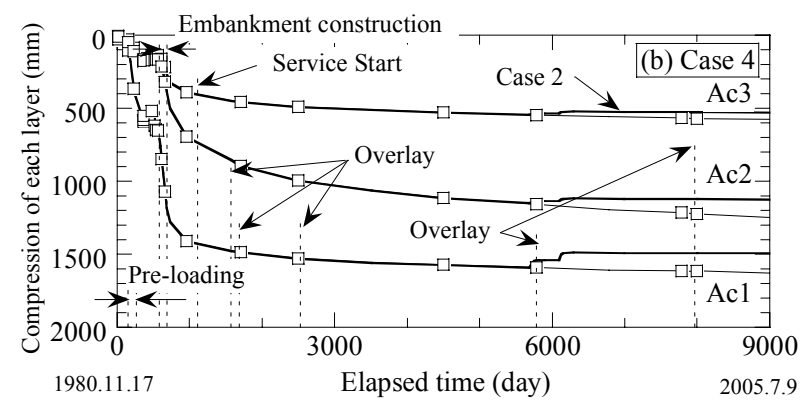

(b) Case 4 と基本ケース（Case 2）との比較

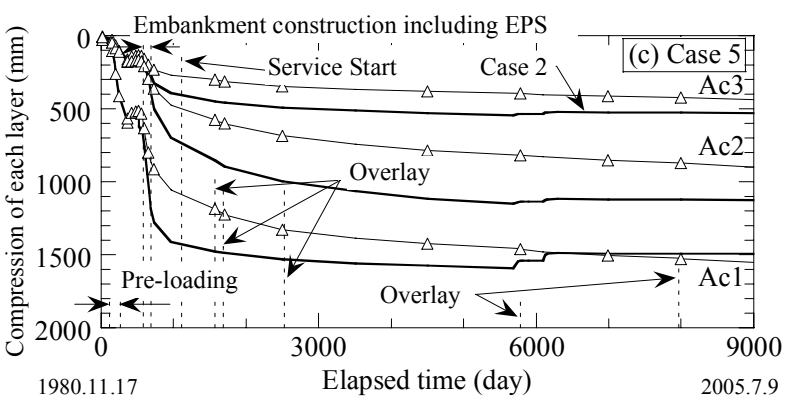

(c) Case 5 と基本ケース（Case 2） との比較

図-16 建設開始からの層別圧縮量の変化

橋台構築直後にEPS盛土を最初から構築した場合であり， 供用開始時点での沈下量は Case 2 よりも小さいものの, 沈下速度が大きく, 解析終了時点での沈下量は Case 2 と ほぼ同程度となっている. Case 3 やC Case 5 のように早期 に荷重軽減を実施したにもかかわらず，最終沈下量が大 きくなる要因として，本章での一連のケースでは，荷重 軽減率を実施工と同一にしている点があげられる. すな わち，A2，A3 橋台構築直後に載荷された盛土荷重は， 実際のプレロードを超えるものであり，軟弱粘土層が正 規圧密状態にいたるため, 大きな沈下が生ずる. 


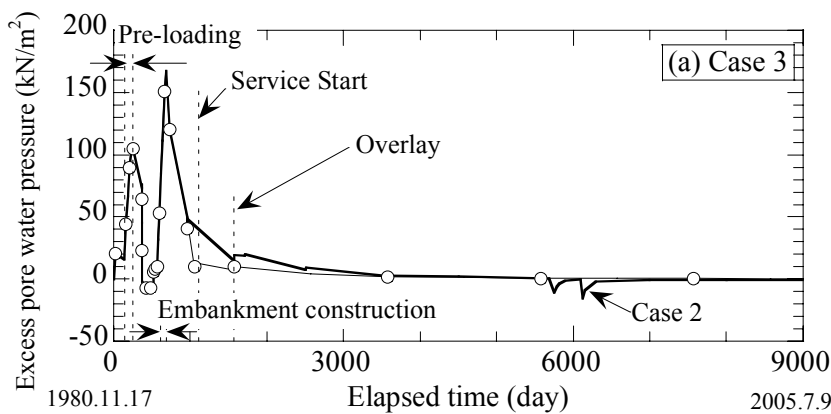

(a) Case 3 と基本ケース（Case 2）との比較

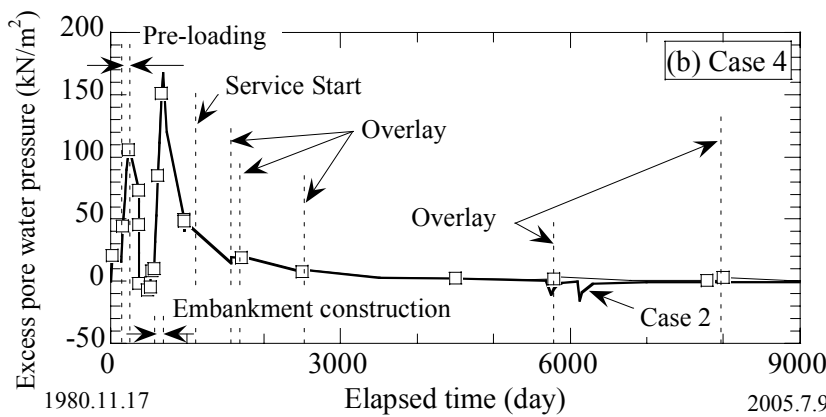

(b) Case 4 と基本ケース（Case 2）との比較

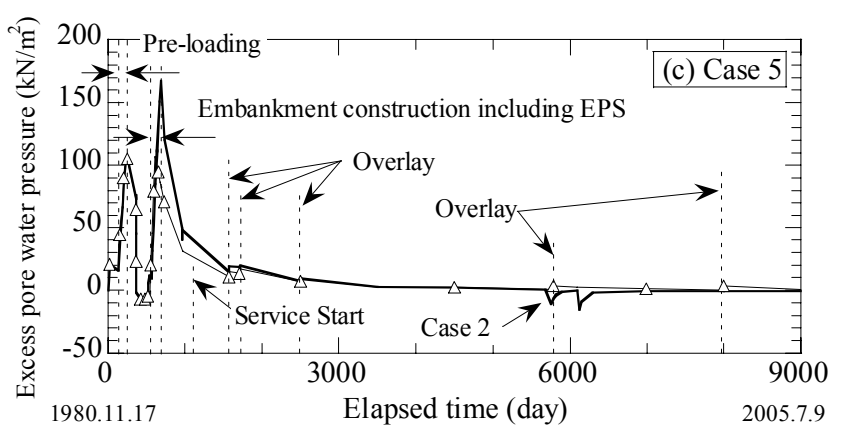

(c) Case 5 と基本ケース（Case 2）との比較

図-17 建設開始からの過剩間隙水圧の変化（Ac2層）

図-16 は，各沖積粘土層の圧縮量の推移を示したもの である. Case 3，4 ではAc2 層のみの圧縮が長期間継続 しているが, Case 5 ではAc1 層の圧縮も長期にわたって いる. Case 5 は本解析ケースの中で最も早期に EPS 盛土 を実施しているものの，EPS と通常盛土をあわせた荷重 が，事前のプレロードよりも約 10\%大きくなっているた め，実質的に荷重軽減になっていないことに起因してい る.

Ac2 層における過剰間隙水圧の経時変化を図-17 に示 した. Case 3 では供用開始時に過㮃間隙水圧がほぼ消散 しており，過剩間隙水圧の消散に伴う沈下が他のケース と比較して抑制されていることと整合する. Case 5 では A2 橋台構築後の背面盛土時に EPS 置換を実施している ために過剩間隙水圧の発生が幾分抑制されているものの, Case 2 との差は Case 3 ほど大きくはない.

図-18 は，供用開始後の橋台上部側方移動量の推移を 比較したものである. Case 3 では，供用開始直前に EPS 置換を実施した影響でその後の移動量の変化は少なく, 橋台の維持管理の観点から好ましい傾向を示している.

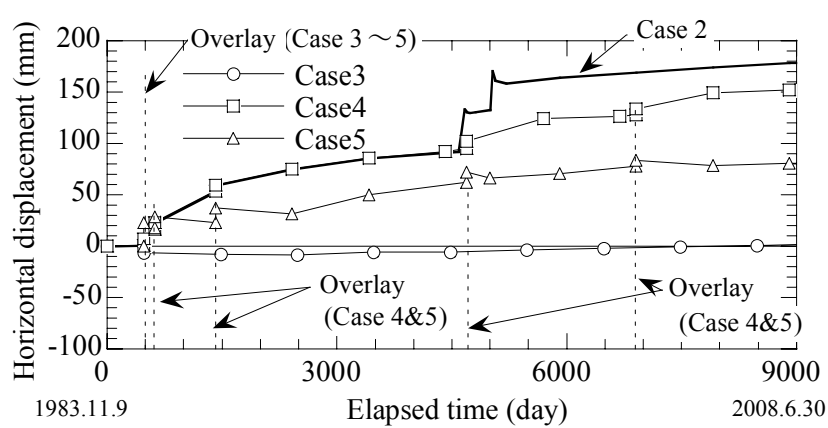

図-18 供用開始からの橋台上部側方移動量の推移 （橋台背面側の移動量を正とする）

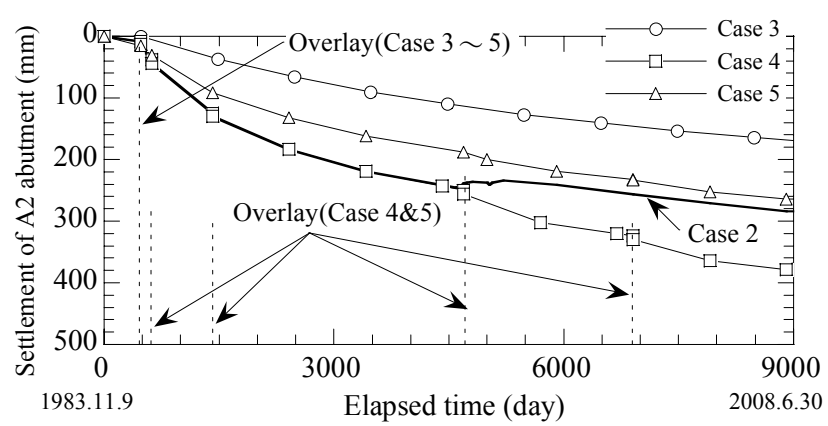

図-19＼cjkstart供用開始からの橋台沈下量

一方, Case 4, 5 では供用開始からも背面側に移動を続け ている. 無対策の Case 4 が EPS による荷重軽減対策を実 施したCase 2 よりもわずかに橋台移動量が小さくなって いるが，最終的な橋台沈下量は Case 2 の方が小さい.

図-19 は供用開始からの橋台沈下量を示したものであ る. 図-15 に示した地表面沈下量と同様に, Case 3 の沈 下抑制効果が顕著である，無対策の場合（Case 4），橋 台の沈下は継続し, Case 2 と比較した差は $10 \mathrm{~cm}$ 近くに も及んでいる. これ以上の “沈下を抑えるための対策” として荷重軽減の効果が認められる。

\section{5. 気泡混合軽量土（FCB）の適用性と対策効果}

\section{（1）基本方針}

気泡混合軽量土 (FCB: Formed Cement Banking) は，現 地発生土や建設残土を利用することが可能であり，軽量 性に加えて, 流動性, 固化後の自立性などの特徴を有し ている. また，練り混ぜ直後の湿潤密度や一軸圧縮強さ を多様に設定することが可能である ${ }^{23)}$. FCB は EPS と比 較して単位体積重量が大きいため盛土に利用した場合の 荷重軽減量は小さいが, 経済性に優れている. 本章では, FCB の利用を前提に, 盛土荷重軽減率队軽減領域を変化 させた解析を行い, その適用性と対策効果を検証した ${ }^{24)}$. 


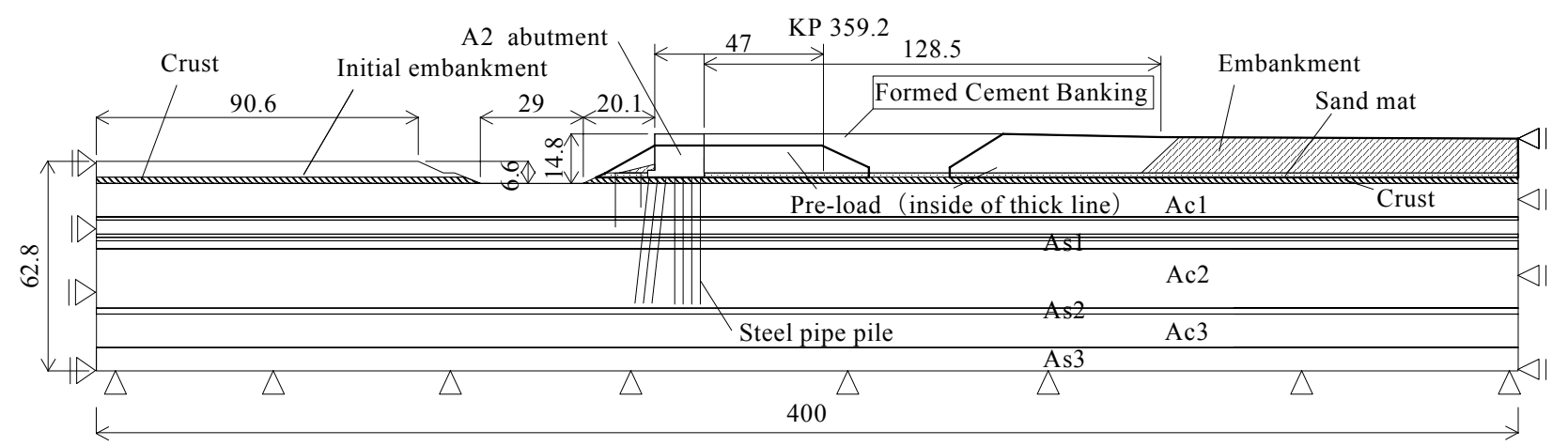

(m)

図-20 解析で用いたモデル図（五貫野高架橋 A2 橋台）

表-6 解析ケース

\begin{tabular}{|c|c|c|c|}
\hline Case & 荷重軽減率 & $\begin{array}{c}\mathrm{FCB} \text { 載荷 } \\
\text { 形状 }\end{array}$ & 備考 \\
\hline Case A & $67 \%$ & \multirow{3}{*}{$\begin{array}{l}\text { 実施工と } \\
\text { 同じ形状 }\end{array}$} & \\
\hline Case B-1 & \multirow{3}{*}{$\begin{array}{c}49 \% \\
\text { 実際の } \\
\text { プレロード } \\
\text { 值から設定 }\end{array}$} & & \\
\hline Case B-2 & & & プレロード全面実施 \\
\hline Case B-3 & & 台形 & \\
\hline Case C & $33 \%$ & 三角形 & \\
\hline
\end{tabular}

\section{（2） 解析モデル}

解析モデルの概要を図-20 に示す．解析上の基本方針 は第 3 章と同じである. FCB は，弾性体としてモデル化 し単位体積重量は既往の事例 ${ }^{25)}$ 参考に $6 \mathrm{kN} / \mathrm{m}^{3}$ とした. 弾性係数は，文献 23)に記載された CBR 值(\%)と一軸圧 縮強さ $q_{\mathrm{u}}\left(\mathrm{kN} / \mathrm{m}^{2}\right)$ との関係 :

$$
\mathrm{CBR}=3.5 q_{u} / 98
$$

に対して CBR 值 $=15 \%$ を想定して得られた $q_{u}=420 \mathrm{kN} / \mathrm{m}^{2}$ を FCB の変形係数と一軸圧縮強さの関係 ${ }^{23)}$

$$
E_{50}=227.3 q_{u}-311.4 \times 98 \quad\left(\mathrm{kN} / \mathrm{m}^{2}\right)
$$

に代入して, $E_{50}=65 \mathrm{MN} / \mathrm{m}^{2}$ とした. ポアソン比は文献 26) を参考に 0.11 とした。 透水係数は文献 23),26),27)を参考 に $8.8 \times 10^{-4} \mathrm{~cm} / \mathrm{s}$ とした.

\section{(3) 解析ケース}

荷重軽減率および荷重軽減範囲を表-6 に示したよう に変化させた 5 ケースの解析を実施した. ここでいう荷 重軽減率とは，本来，高さ $11.7 \mathrm{~m}$ の通常盛土を行うべき ところを FCB で構築することによる, 全上載圧の軽減率 のことで，次式で定義した.

$$
\text { 荷重軽減率 }=1-\frac{\text { 荷重軽減後の全上載荷重 }}{\text { 通常盛土の場合の全上載荷重 }}
$$

すなわち，荷重軽減率が大きいほど，より多くの荷重 を軽減させることになる. なお, 荷重軽減率は, ある断
面に着目した值ではなく，荷重軽減区間全体の軽減率を 示している.

表-6の各ケースの位置付けは，以下の通りである. す ベてのケースに関して，橋台背面の縦断方向荷重軽減延 長は $128.5 \mathrm{~m}$ であり, 基本ケース (Case 2) と同じである. 各ケースに対する FCB 盛土範囲を図-21 に示す.

Case A‥橋台背面盛土をすべて FCB とした場合.

Case B ‥Case A のように全断面にFCB工法を実施するの ではなく，プレロード実績に基づき軽減率を設定する.

Case B では, FCB 盛土断面形状および事前のプレロード 範囲を変化させた 3 種類のケースについて解析を実施し た. 施工上可能であったプレロード值を 1.2 で除した荷 重に相当する荷重軽減率は 49\%となる. Case B-1 は，実 施工と同様な縦断断面形状の FCB 盛土範囲とした場合, Case B-2 では, Case B-1 と同様の条件で事前に行うプレ ロード範囲をFCB 盛土範囲全体とした場合, Case B-3 は, A2 橋台への擦り付けを考え改良範囲を図-21(d)に示す 台形形状とした場合を想定したものである。図-21(d)に 示す CaseB-3 での台形面積は Case B-1 と等しくした.

Case C‥Case BよりもさらにFCB盛土範囲を小さくした 場合を想定. FCB 縦断盛土形状は，橋台背面にすりつけ るものとして，三角形とした。

\section{（4） 解析上の施工工程}

解析上の施工工程は，A2 橋台構築までは基本ケース （Case 2）と同様であるが，当初から軽量材を使用する ことを前提としたため，砂利杭打設や A3 橋台の設置は 考慮していない. また, 表-7 に示すオーバーレイ回数は, 前章と同様な方法で設定した。

\section{(5) 解析結果}

解析で得られた橋台背面地盤（KP 359.2）の沈下量を 図-22 に示す.

Case A では，A2 橋台背面すべてを FCB で盛土するこ とによって通常盛土の 1/3 の荷重しか作用していないた め, 沈下速度は Case 2 (基本ケース) と比較して小さい. 


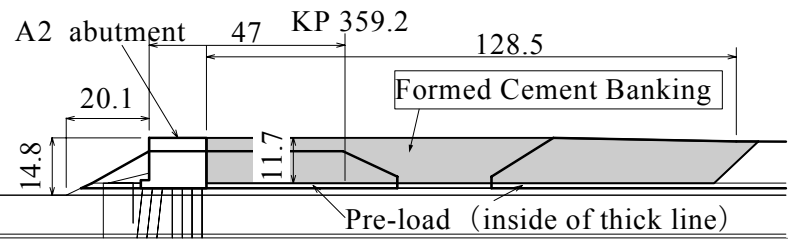

(a) Case $\mathrm{A}$

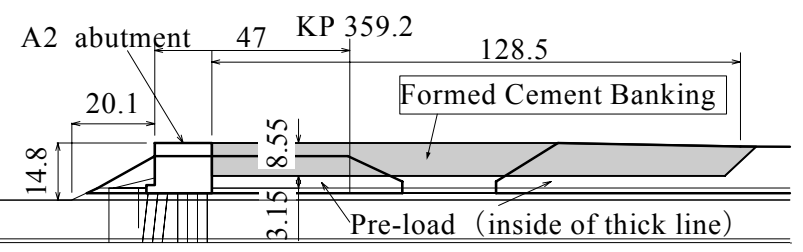

(b) Case B-1

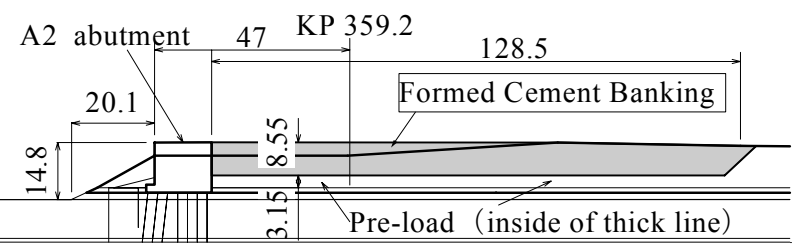

(c) Case B-2

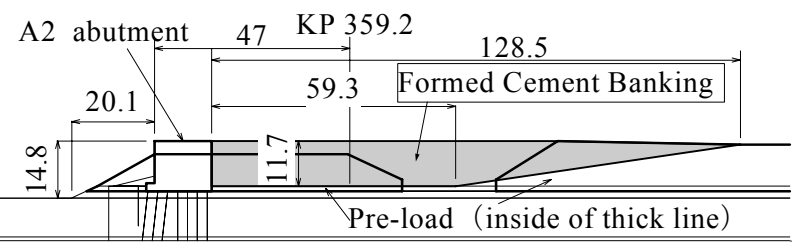

(d) Case B-3

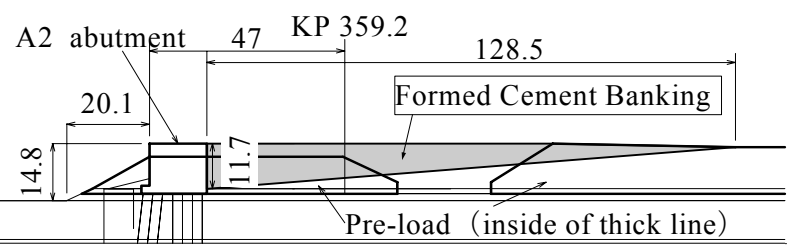

(e) Case $\mathrm{C}$

(m)

図-21 各解析ケースにおける FCB 盛土断面形状

表-7 オーバーレイ回数と実施時期

\begin{tabular}{|c|c|c|c|c|c|}
\hline \multirow{2}{*}{ Case } & \multirow{2}{*}{$\begin{array}{c}\text { オーバ } \\
\text { ーレイ } \\
\text { 回数 }\end{array}$} & \multicolumn{4}{|c|}{ 実施時期 } \\
\hline & & 1 回目 & 2 回目 & 3 回目 & 4 回目 \\
\hline $\mathrm{A}$ & 3 & \multirow{5}{*}{1985.3} & \multirow{5}{*}{1985.7} & \multirow{5}{*}{1987.9} & \\
\hline B-1 & 3 & & & & 1996.9 \\
\hline B-2 & 1 & & & & \\
\hline B-3 & 5 & & & & 1996.9 \\
\hline $\mathrm{C}$ & 5 & & & & \\
\hline
\end{tabular}

解析終了時点の総沈下量も Case 2 の半分程度である.

Case Bでは, Case A よりも荷重軽減率が小さいために 最終沈下量は Case A と比較して大きい. Case B-2 では, FCB 構築範囲 $(128.5 \mathrm{~m})$ 全面にプレロードを実施してい るため，他のケースと比較してこれに起因する沈下が大 きくなっている. その後の FCB による盛土は Case B-1 と同範囲のため Case B-1 と同様の沈下傾向を示している.

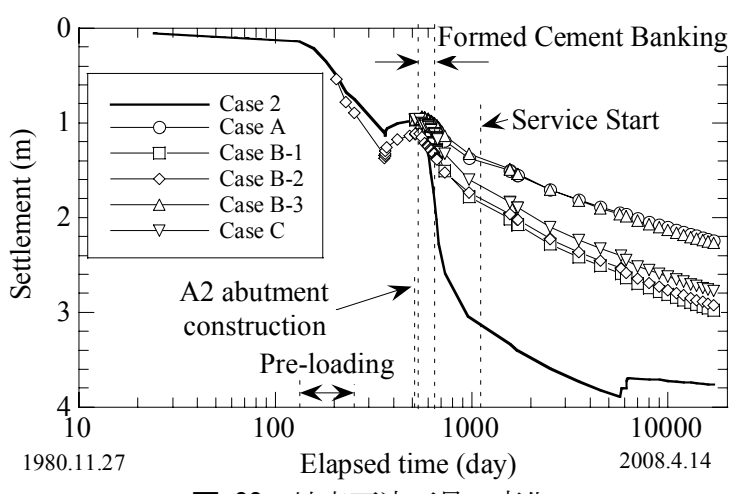

図-22 地表面沈下量の変化

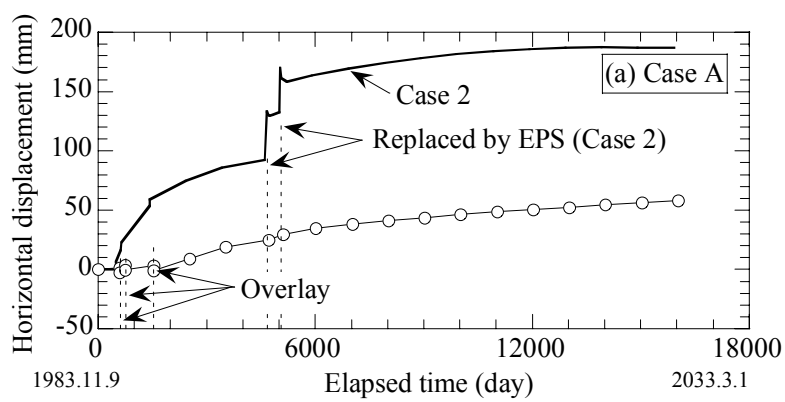

(a) Case $\mathrm{A}$

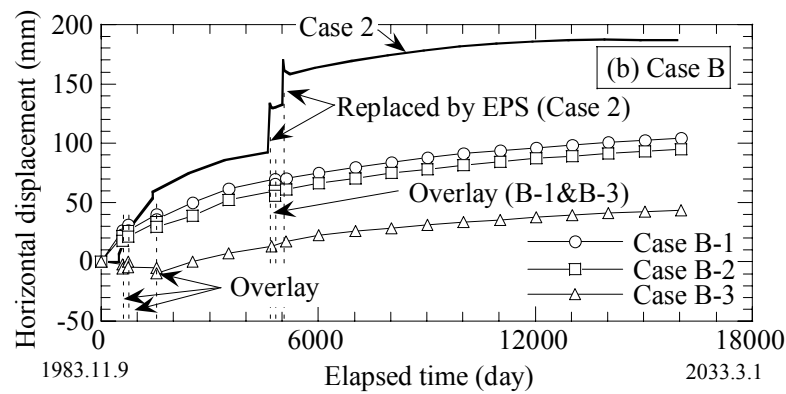

(b) Case B

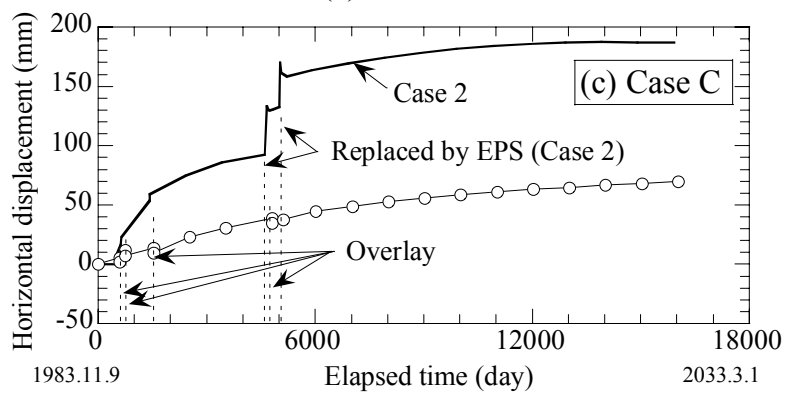

(c) Case C

図-23 橋台側方移動量の推移

(橋台背面側の移動量を正とする)

しかし, Case B-3 は地表面沈下量を判定した KP 359.2 地 点での荷重軽減率は Case A と同じであるためにその他 の 2 ケースと異なりこの地点の沈下量が小さく評価され ている.

Case Cでは，今回実施した解析の中で最も荷重軽減率 が小さいにもかかわらず，最終沈下量は Case B-1, B-2 と比較して小さくなっている.

しかしながら，後述の表-10 に示すように，供用開始 からの沈下量はすべてのケースで基本ケース（Case 2) を上回っており, 道路機能を確保するための縦断線形や 


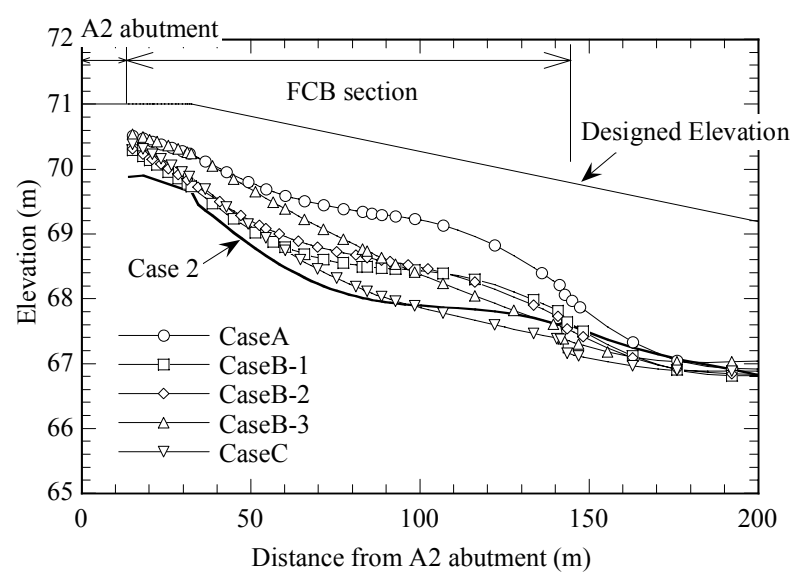

図-24 供用開始から 44 年後の縦断線形

オーバーレイ回数に影響を及ぼしている.

図-23 は，橋台上部側方移動量の推移を比較したもの であるが，沈下にともなって橋台が背面側に移動してい ることがわかる. Case A や Case B-3, Case C のように, 橋台背面直近の盛土高すべてにわたって FCB を構築し た場合の橋台移動量は，他のケースと比較して小さい.

以上の検討では，FCB による対策効果を判断するにあ たって, 橋台移動量や, 動態観測が行われた KP 359.2 地 点での地表面沈下量をとりあげた. これらに加えて, 縦 断線形の変化は道路の機能を考えた場合の重要な検討項 目の一つであり，これを比較する目的で解析終了時（供 用開始から 44 年後）の縦断線形を図-24に示した. Case B のように荷重軽減率も施工時期も同じであるにも係わ
らず荷重軽減範囲形状が異なると最終的な縦断線形も異 なる，また，Case Cでは，橋台直近付近での沈下量は抑 制されているものの, 橋台から離れるにつれて大きくな っており，維持管理上，留意すべき点である.

\section{6. 維持管理・対策費用からみた対策工の検討}

\section{（1） 維持管理・対策費用の調査}

本章では既往の工事記録あるいは設計計算書をもとに， 五貫野高架橋に関わる対策工や補修頻度および維持管理 費用の調査を行い，前章の各解析ケースに相当するシナ リオをとった場合の対策費用，維持管理費用を概算し， コストと効果の観点から最善の対策工を検討する.なお, 本来は，金利も総費用に影響を及ぼすはずであるが，本 検討では考慮していない，また，以下の対策費用は実際 の施工に際しての事前検討段階の資料に基づくものであ り，かつ，実際の工事に伴う諸経費は含まれていない.

五貫野高架橋関連資料 ${ }^{28)}$ によれば，同高架橋を含む道 路区間に関して，高架橋が供用開始された 1983 年から 1989 年度までの 7 年間の維持管理費用総額は約 40,000 千円 $/ \mathrm{km}$ に達している，補修項目としては，舗装改良が 最も多く，その他，周辺地盤対策として田面客土，段差 修正，支承改良の順となっている.

\section{a） 対策工費用}

控え式鋼矢板工法，砂利杭工法，アプローチクッショ ン方式橋台（A3 橋台）ならびに，EPS 工法の費用に関

表-8 荷重軽減時期を変化させた場合の対策効果と必要対策項目の比較

\begin{tabular}{|c|c|c|c|c|c|}
\hline \multicolumn{2}{|c|}{ 解 析 ケース } & Case 2 & Case 3 & Case 4 & Case 5 \\
\hline \multicolumn{2}{|r|}{ 概 } & 実施工条件 & $\begin{array}{l}\mathrm{A} 3 \text { 橋台構築直後 } \\
\text { に荷重軽減を実施 }\end{array}$ & $\begin{array}{l}\text { 荷重軽減を } \\
\text { 実施しない }\end{array}$ & $\begin{array}{l}\text { A2 橋台構築直後に } \\
\text { 荷重軽減を実施 }\end{array}$ \\
\hline \multicolumn{2}{|c|}{ 施工開始からの地表面総沈下量(解析結果) } & $3,761 \mathrm{~mm}$ & $3,543 \mathrm{~mm}$ & $4,267 \mathrm{~mm}$ & $3,613 \mathrm{~mm}$ \\
\hline \multicolumn{2}{|c|}{ 供用開始からの地表面沈下量(解析結果) } & $647 \mathrm{~mm}$ & $475 \mathrm{~mm}$ & $1,153 \mathrm{~mm}$ & $1,398 \mathrm{~mm}$ \\
\hline \multicolumn{2}{|c|}{ 橋台設置後の総移動量(解析結果) ${ }^{\text {注1) }}$} & $18 \mathrm{~mm}$ & $-77 \mathrm{~mm}$ & $-4 \mathrm{~mm}$ & $-20 \mathrm{~mm}$ \\
\hline \multicolumn{2}{|c|}{ 供用開始からの橋台移動量(解析結果) } & $187 \mathrm{~mm}$ & $12 \mathrm{~mm}$ & $165 \mathrm{~mm}$ & $110 \mathrm{~mm}$ \\
\hline \multicolumn{2}{|c|}{ 控え式鋼矢板工法 } & $\bigcirc^{\text {注2) }}$ & $\bigcirc$ & $\bigcirc$ & $\bigcirc$ \\
\hline \multicolumn{2}{|c|}{ 砂利杭工法 } & $\bigcirc$ & $\bigcirc$ & O & O \\
\hline \multicolumn{2}{|c|}{ アプローチクッション方式橋台(A3 橋台) } & $\bigcirc$ & $\bigcirc$ & O & $x$ \\
\hline \multicolumn{2}{|c|}{ EPS による荷重軽減対策 } & O & $\bigcirc$ & $\times$ & O \\
\hline \multicolumn{2}{|c|}{ 段差修正 } & $\bigcirc$ & $\bigcirc$ & $\bigcirc$ & O \\
\hline \multicolumn{2}{|c|}{ オーバーレイ回数 } & 3 回 & 1 回 & 5 回 & 5 回 \\
\hline \multirow{2}{*}{ 支承改良 } & 切り欠き回数 & - & 1 回 & - & - \\
\hline & 下沓位置変更回数 & 1 回 & - & 1 回 & 1 回 \\
\hline \multicolumn{2}{|c|}{ 家屋の補修回数 } & 2 回 & 2 回 & 4 回 & 4 回 \\
\hline
\end{tabular}

注 1) 橋台背面側への移動を正とする

注 2) $\bigcirc$ : 当該対策を実施， $\times$ : 当該対策を実施せず 
しては，既往の資料を参照したＦCB 工法については， $1 \mathrm{~m}^{3}$ 当り 10 千円と仮定した.

\section{b) 維持管理費用}

段差修正工…段差修正は, 残留沈下によって橋台などの 取付部に生じた段差を緩和するために実施されるもので, 実施の目安は橋台取付部の場合は, すり付け勾配が $0.5 \%$ 以上になった場合とされている29). 文献 29)に記載 された，段差修正費用と供用開始からの沈下量との関係 式より算定した.

$$
\mathrm{Y}=0.687 \mathrm{X}-7.849
$$

$(\mathrm{Y}$ : 段差修正費用（百万円），X : 沈下量 $(\mathrm{cm}))$

オーバーレイエ…オーバーレイは, 縦断曲線長や縦断曲 率半径などの縦断線形が支障をきたした際に実施される。 五貫野高架橋の場合, 延長 $100 \mathrm{~m}$ のオーバーレイ費用は 4 車線当り約 7,000 千円であった.

支承改良工 ‥五貫野高架橋では供用開始時点より A2 橋 台の支承の遊間に変状がみられ，1987 年度に上部工のジ ヤッキアップを行い, 下沓位置の変更を実施している.

資料によれば, 下沓位置変更費用は約 22,000 千円となっ ている.

周辺家屋の補修…本線盛土の沈下量と隣接寸る家屋の沈 下量には相関関係が見られ，盛土の沈下量を 1 とした場 合, $15 \mathrm{~m}$ 離れた家屋の沈下量は 0.26 という比率が得られ ている. 1987 年以後 30 年間の本線盛土の累積沈下量が $123 \mathrm{~cm}$ と予想されていることから, 家屋の累積沈下量は $32 \mathrm{~cm}$ となり補修対策が必要である. 具体的には, 2 回に
わたる家屋のジャッキアップが考えられているが，実際 に実施されたかは不明である。資料によれば，概算費用 は 1 回当り約 5,000 千円と記載されている.

\section{（2）対策効果と維持管理費用の比較}

前章までに示した数值解析結果を基に, 施工から供用 中の維持管理に至るまでの費用を概算した.

\section{a） 荷重軽減時期を変化させた場合}

表-8 は, 第4 章で実施した各解析から得られた供用開 始からの地表面沈下量および橋台移動量, ならびに想定

表-9 荷重軽減時期を変化させた場合の対策費用の比較

\begin{tabular}{|c|c|c|c|c|c|}
\hline \multirow{2}{*}{\multicolumn{2}{|c|}{ 項 目 }} & \multicolumn{4}{|c|}{ 解析ケース } \\
\hline & & Case 2 & Case 3 & Case 4 & Case 5 \\
\hline \multicolumn{2}{|c|}{ 控え式鋼矢板工法 } & 15,000 & 15,000 & 15,000 & 15,000 \\
\hline \multicolumn{2}{|c|}{ 砂利杭工法 } & 50,000 & 50,000 & 50,000 & 50,000 \\
\hline \multicolumn{2}{|c|}{ A3 橋台 } & 62,000 & 62,000 & 62,000 & 0 \\
\hline \multicolumn{2}{|c|}{ EPS 工法 } & 388,790 & 300,690 & 0 & 285,090 \\
\hline \multicolumn{2}{|c|}{ 段差修正 } & 36,600 & 24,800 & 71,400 & 88,200 \\
\hline \multicolumn{2}{|c|}{ オーバーレイ } & 42,000 & 14,000 & 70,000 & 70,000 \\
\hline 支承 & 切り欠き & 0 & 1,000 & 0 & 0 \\
\hline 改良 & 下沓位置変更 & 22,000 & 0 & 22,000 & 22,000 \\
\hline \multicolumn{2}{|c|}{ 家屋の補修 } & 10,000 & 10,000 & 20,000 & 20,000 \\
\hline \multicolumn{2}{|c|}{$\begin{array}{c}\text { 合 計 } \\
\text { (Case 2 に対する比率) }\end{array}$} & $\begin{array}{c}626,390 \\
(1.00)\end{array}$ & $\begin{array}{c}477,490 \\
(0.76)\end{array}$ & $\begin{array}{c}310,400 \\
(0.50)\end{array}$ & $\begin{array}{c}550,290 \\
(0.88)\end{array}$ \\
\hline
\end{tabular}

表-10 解析結果および対策工, 維持補修工の回数

\begin{tabular}{|c|c|c|c|c|c|c|c|}
\hline \multicolumn{2}{|c|}{ 解 析 ケース } & Case 2 & Case A & Case B-1 & Case B-2 & Case B-3 & Case $\mathrm{C}$ \\
\hline \multirow{2}{*}{\multicolumn{2}{|c|}{$\begin{array}{c}\text { 概 要 } \\
\text { 施工開始からの地表面総沈下量(解析結果) }\end{array}$}} & 実施工 & \multicolumn{5}{|c|}{ A2 橋台構築後, 背面側を FCB 工法で構築 } \\
\hline & & $3,761 \mathrm{~mm}$ & $2,244 \mathrm{~mm}$ & $2,976 \mathrm{~mm}$ & $2,928 \mathrm{~mm}$ & $2,270 \mathrm{~mm}$ & $2,776 \mathrm{~mm}$ \\
\hline \multicolumn{2}{|c|}{ 供用開始からの地表面沈下量(解析結果) } & $647 \mathrm{~mm}$ & $840 \mathrm{~mm}$ & $1,156 \mathrm{~mm}$ & $1,152 \mathrm{~mm}$ & $910 \mathrm{~mm}$ & $1,131 \mathrm{~mm}$ \\
\hline \multicolumn{2}{|c|}{ 橋台設置後の総移動量(解析結果)注 1) } & $18 \mathrm{~mm}$ & $-54 \mathrm{~mm}$ & $-11 \mathrm{~mm}$ & $16 \mathrm{~mm}$ & $-171 \mathrm{~mm}$ & $-177 \mathrm{~mm}$ \\
\hline \multicolumn{2}{|c|}{ 供用開始からの橋台移動量(解析結果) } & $187 \mathrm{~mm}$ & $56 \mathrm{~mm}$ & $99 \mathrm{~mm}$ & $91 \mathrm{~mm}$ & $43 \mathrm{~mm}$ & $69 \mathrm{~mm}$ \\
\hline \multicolumn{2}{|c|}{ 荷重軽減率 } & $34.4 \%$ & $67 \%$ & & $49 \%$ & & $33 \%$ \\
\hline \multicolumn{2}{|c|}{ プレロード条件 } & 実施工 & \multicolumn{2}{|c|}{ Case 2 と同じ } & $\begin{array}{l}\text { A2 橋台背面 } \\
\text { 全面で実施 }\end{array}$ & \multicolumn{2}{|c|}{ Case 2 と同じ } \\
\hline \multicolumn{2}{|c|}{ 荷重軽減対策 } & EPS & \multicolumn{5}{|c|}{ FCB による荷重軽減 } \\
\hline \multicolumn{2}{|c|}{ 荷重軽減部縦断面形状 } & 実施工 & \multicolumn{3}{|c|}{ 実施工と同様 } & 台形 & 三角形 \\
\hline \multicolumn{2}{|c|}{ 段差修正 } & $\bigcirc^{\text {注2) }}$ & $\bigcirc$ & $\bigcirc$ & $\bigcirc$ & $\bigcirc$ & $\bigcirc$ \\
\hline \multicolumn{2}{|c|}{ オーバーレイ回数 } & 3 回 & 3 回 & 4 回 & 4 回 & 3 回 & 3 回 \\
\hline \multirow{2}{*}{ 支承改良 } & 切り欠き回数 & - & - & - & - & 1 回 & - \\
\hline & 下沓位置変更回数 & 1 回 & 1 回 & 1 回 & 1 回 & - & 1 回 \\
\hline \multicolumn{2}{|c|}{ 家屋の補修回数 } & 2 回 & 3 回 & 4 回 & 4 回 & 3 回 & 4 回 \\
\hline
\end{tabular}

注 1) 橋台背面側への移動を正とする

注 2) $\bigcirc$ : 当該対策を実施， $\times$ : 当該対策を実施せず 
した対策工，維持管理工の項目およびその回数を示した ものである. 家屋の補修回数は実施工で想定されている 回数と供用開始からの地表面沈下量の関係を基に，支承 改良回数については, 供用開始からの橋台移動量を基に 想定した. オーバーレイ回数は, 第 4 章の解析で考慮し た回数とした.

橋台支承の補修は，供用開始からの橋台移動量が $50 \mathrm{~mm}$ 未満の場合についてはストッパーの切り欠きによ る対策を，50mm 以上の移動量については，支承の移動 余裕量を確保するため, 下沓位置変更による対策を実施 するものとした.

表-9 は，以上の前提に基づき，第 4 章で実施したそれ ぞれの解析ケースに対して, 対策および維持補修費用の 総額を比較したものである. なお, Case 3 における EPS 工法費用が Case 2 よりも小さいのは, Case 3 では供用開 始前の対策を前提とするため, 車線毎に工事を行う必要 がなく土留め工が不要であること, 供用開始前であれば EPS 置換の際に発生する既存一般盛土を他の盛土施工箇 所に転用することが可能であり残土処理が不要であるた めである．また，Case 5 における EPS 工法費用が Case 3 よりさらに小さくなっているのは, Case 5 では舗装前の 荷重軽減を想定しているため, 既存舗装の取壊が不要と 判断したためである.

\section{b）FCBによる対策を想定した場合}

FCB による対策を想定した解析結果をもとに同様の 検討を行う. 表-10 は，各解析ケースにおける供用開始 からの地表面沈下量および橋台移動量, ならびに対策工, 維持補修工の項目およびその回数を示したものである.
表-11 は第 5 章で実施したそれぞれの解析ケースに対 して, 対策および維持補修費用総額を比較したものであ る.

\section{（3）費用と対策効果からみた比較検討}

図-25〜27 は，橋台背面盛土部分（KP 359.2 地点）の 地表面沈下量と橋台上部水平変位および橋台沈下量に関 して, 各ケースに対する費用試算結果との関係をまとめ たものである. 対策効果をこれらの項目のみで判断する ことはできないものの，これらの沈下や変異を抑制する ことによって周辺地盤や橋台, 路面縦断線形などへの影 響も少なくなることから検討の意義はあるものと判断し た.

なお，図-25～27 の横軸は，Case 2（基本ケース）の費 用で正規化している.これらの図から，以下のことがわ かる.

・荷重軽減時期を変化させたパラメトリックスタディ (Case 2～5) に着目した場合, Case 4 (荷重軽減を実施 しない）の費用は, Case 2 (実施工ケース) の約 1/2 であるが，施工開始からの地表面沈下量や供用開始 からの橋台沈下量が大きい. 特に, 橋台が沈下寸る ことによって高架橋上部工が終局状態となることが 想定されているため, 同高架橋に適用することはで きない.

- Case 4 のように, 供用後の維持管理のみで道路機能を 満足させることが明確な場合には, 表-9 に示したよ うに，総費用は低くなる. しかしながら，今回扱っ た問題のように，供用中に想定以上の沈下や変形が 発生した場合には, 別途供用中の対策工が必要とな

表-11 対策工および維持補修費用

\begin{tabular}{|c|c|c|c|c|c|c|c|}
\hline \multirow{2}{*}{\multicolumn{2}{|c|}{ 項 目 }} & \multicolumn{6}{|c|}{ 解析ケース } \\
\hline & & Case 2 & Case A & Case B-1 & Case B-2 & Case B-3 & Case C \\
\hline \multicolumn{2}{|c|}{ 控え式鋼矢板工法 } & 15,000 & 15,000 & 15,000 & 15,000 & 15,000 & 15,000 \\
\hline \multicolumn{2}{|c|}{ 砂利杭工法 } & 50,000 & 0 & 0 & 0 & 0 & 0 \\
\hline \multicolumn{2}{|c|}{$\begin{array}{l}\text { アプローチクッション } \\
\text { 方式橋台 (A3 橋台) }\end{array}$} & 62,000 & 0 & 0 & 0 & 0 & 0 \\
\hline \multicolumn{2}{|c|}{ EPS 工法 } & 388,790 & 0 & 0 & 0 & 0 & 0 \\
\hline \multicolumn{2}{|l|}{ FCB 工法 } & 0 & 375,800 & 274,600 & 274,600 & 274,600 & 187,900 \\
\hline \multicolumn{2}{|l|}{ 段差修正 } & 36,600 & 49,900 & 71,600 & 71,300 & 54,700 & 69,900 \\
\hline \multicolumn{2}{|c|}{ オーバーレイ } & 42,000 & 42,000 & 56,000 & 56,000 & 42,000 & 42,000 \\
\hline \multirow{2}{*}{ 支承改良 } & 切り欠き & 0 & 0 & 0 & 0 & 1,000 & 0 \\
\hline & 下沓位置変更 & 22,000 & 22,000 & 22,000 & 22,000 & 0 & 22,000 \\
\hline \multicolumn{2}{|c|}{ 家屋の補修 } & 10,000 & 15,000 & 20,000 & 20,000 & 15,000 & 20,000 \\
\hline \multicolumn{2}{|c|}{$\begin{array}{c}\text { 合 計 } \\
\text { (Case 2 に対する比率) }\end{array}$} & $\begin{array}{c}626,390 \\
(1.00)\end{array}$ & $\begin{array}{c}519,700 \\
(0.82)\end{array}$ & $\begin{array}{c}459,200 \\
(0.73)\end{array}$ & $\begin{array}{c}458,900 \\
(0.73)\end{array}$ & $\begin{array}{c}402,300 \\
(0.64)\end{array}$ & $\begin{array}{c}356,800 \\
(0.57)\end{array}$ \\
\hline
\end{tabular}




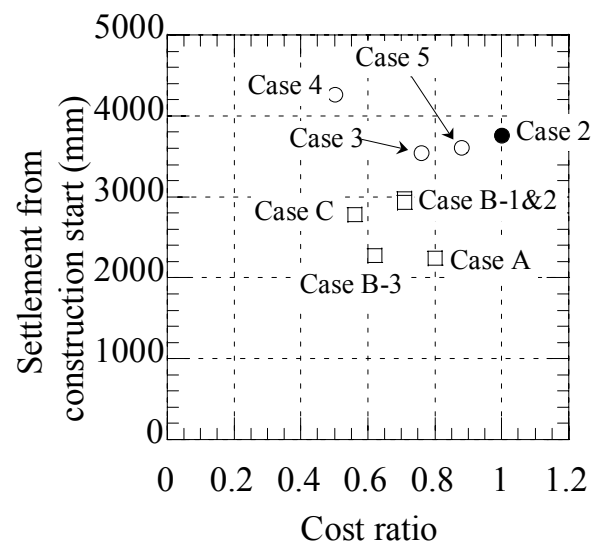

(a) 施工開始からの沈下量

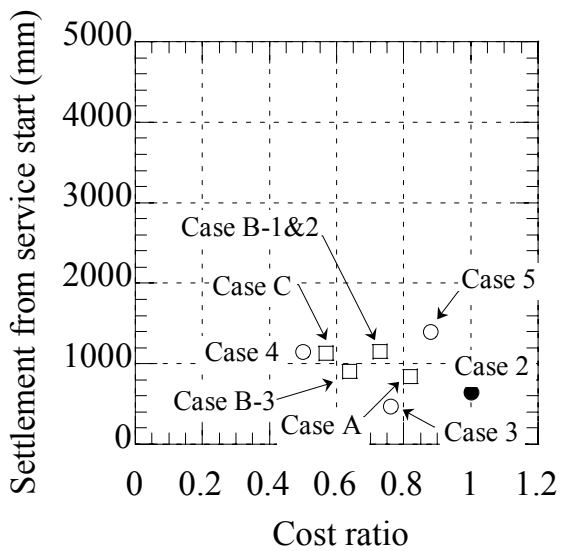

(b) 供用開始からの沈下量

図-25＼cjkstart費用と橋台背面盛土の沈下量との関係（KP359.2 地点）

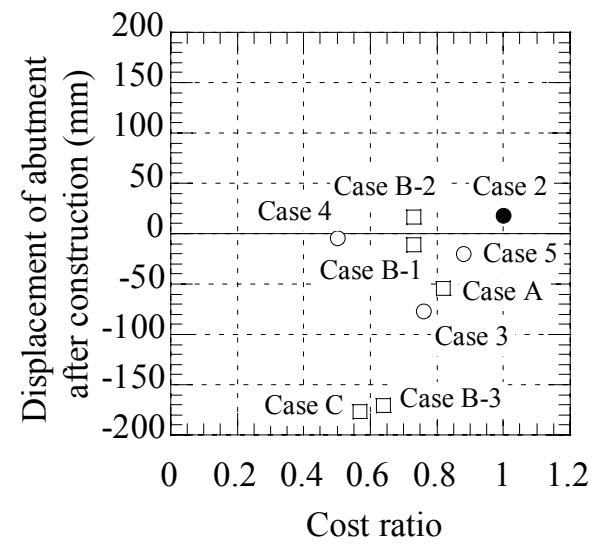

(a) 橋台設置時点からの変位量

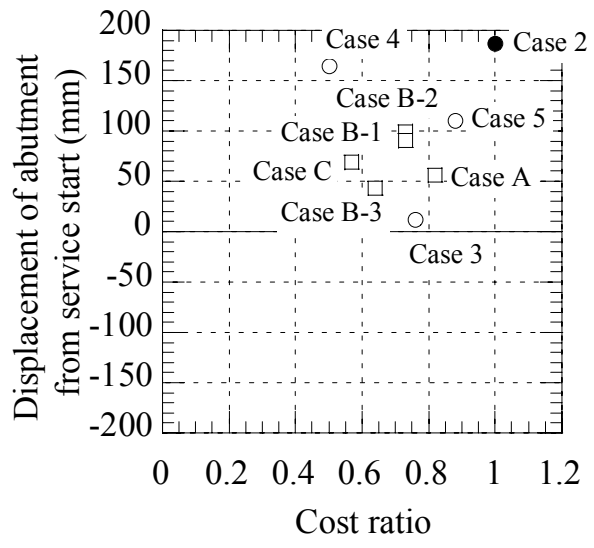

(b) 供用開始からの変位量

図-26 費用と橋台上部水平変位量との関係（橋台背面側への移動を正と寸る）

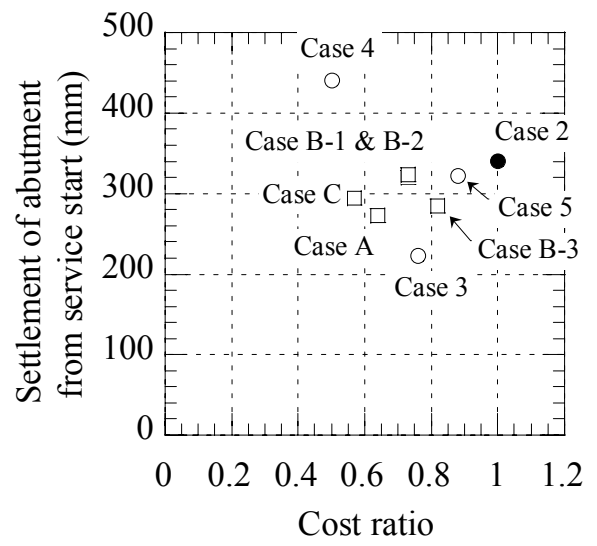

図-27費用と橋台沈下量との関係

り, 最終的な対策費用が高価になるというリスクが ある．そのためにも事前予測の精度に十分な注意を 払う必要がある。

- Case 3 (A3 橋台構築直後に EPS による荷重軽減) と Case 5（A2 橋台構築直後に当初から EPS 施工）は, それぞれ実施工の $76 \%, 88 \%$ のコストで対策が可能と なる．通常盛土を実施した Case 3 では盛土荷重が実 質的にプレロードとして機能しており，供用開始後 の地表面沈下量および橋台変位量が小さくなってい る. 荷重軽減時期を変化させたケース（Case 2～5）
の中では, Case 3 のシナリオが最も効果的であると考 えられる.

・ FCB による対策効果に着目したケース（Case A〜C) では, 橋台変位量と施工開始からの地表面沈下量は すべてのケースで Case 2 (実施工ケース) よりも小さ くなった. 特にCase A, Case B-3 では実施工と比較 して約 40\%の沈下量低減効果が認められる. 加えて Case B-3 では縦断線形も良好であり, 費用も基本ケー スの $64 \%$ であることから，この解析ケースの中では 最も効果的である. その反面, 供用開始からの地表 
面沈下量はすべてのケースで, Case 2 よりも大きくな っており, 維持管理に関連して留意すべき点である.

通常，構造物の性能を向上させるためには，より高い コストが必要とされるが, 本論文で示した一連の結果は, 対策時期や対策方法を工夫寸ることにより，効率的に高 い性能を達成することの可能性を示している. これらの 効果を事前に精度よく予測可能であることが前提であり, そのための, 計測データの蓄積と設計へのフィードバッ クが重要である.

\section{7. まとめ}

本論文では，実在する道路高架橋の沈下変形対策問題 を対象とした縦断面有限要素解析を通して, 同橋台の最 適な対策工を対策効果（性能）とコストの観点から検討 した. 本論文で得られた知見を以下にまとめる.

1) 本論文で扱った高架橋では，供用開始から長期間を 経た段階で, 抜本的な対策としてEPSによる荷重軽 減が実施された。一連の解析を通して沈下や橋台変 位抑制効果を無対策の場合と比較し，EPS による盛 土荷重軽減対策の有效性を確認した. 寸なわち，あ る程度の期間が経過した段階でも, 荷重軽減を行っ た際の橋台変位や沈下抑制効果は認められる.

2) EPS による荷重軽減時期を変化させたパラメトリッ クスタディによれば, 荷重軽減対策を早期に行う方 が, より少ない投資で, より大きな効果が得られる. すなわち, 将来, 設計上の予想を上回る変状が予期 された，できるだけ早い段階で対策を施すのが経済 的である.

3）逆にいえば，同じ規模の対策でも，対策を講じる時 期によって対策効果に差が生ずる．このような問題 を扱うに際しては，時間項を考慮することが対策工 の設計精度を高めるために重要である.

4) 同一高架橋を対象に, 気泡混合軽量土（FCB）を用 いた対策の適用性を解析的に検証した. その結果, EPSよりも単位体積重量が大きいFCBを用いる場合 でも，対策時期や範囲を工夫寸ることによって，十 分な効果を得ることが可能であることが判明した.

5) 荷重軽減対策効果を推定するには, 荷重軽減前の地 盤や構造物の状態を的確に把握する必要がある. そ のためには，本論文で扱ったような施工過程を考慮 可能なモデル化が重要である. また，モデル化の精 度に影響を及ぼす施工履歴, 補修や維持管理履歴は 供用開始後も長期間にわたって一括管理されること が望ましい.

6) 対策工の設計精度を向上させるためにも, 将来, 過
大な沈下が生ずる可能性がある区間では, 施工過程 から供用時にいたる動態観測を継続的に行うことが 望ましい.

7) EPS やFCB による荷重軽減を伴う対策では, 荷重軽 減時期のみならず, 荷重軽減率も対策効果を左右す る大きな要因である.

本論文で示した解析事例では, 将来の機能喪失（性能 未達）が予見された早い段階での対策が，より有効であ ることを示唆するものである. 換言すれば, 将来の問題 が予見された場合, 機能が十分に低下していない, ある 程度健全な状態で, 将来を見越して対策を講ずることが 対投資効果からすると有効であることを示唆している. このような将来を見越した投資は，社会の十分な合意が なければ難しいことも事実であり，今後，このような土 構造物の挙動予測技術とその精度の向上に対する実績を さらに積み上げ社会に認知されていく必要がある.また, 予測精度を向上させるためには，施工中および供用中の 動態観測が重要であることに加えて, 本論文の冒頭で述 ベたような建設前の試験盛土が有効である. 試験盛土を 実施することでその情報を基にした解析の信頼性が格段 に向上し，その結果，維持管理・対策費用を低減できる 可能性がある.

謝辞: 本論文で対象とした保倉川地区 五貫野高架橋の貴 重な施工記録をご提供して頂いた東日本高速道路株式会 社 新潟管理局 上越管理事務所に感謝の意を表します.

\section{参考文献}

1) 太田秀樹: 維持・管理および更新のための計測・解析技術, 土と基礎，5月号，pp.1-6，2004.

2) 山海堂 : 性能設計時代の橋梁下部構造の設計・施工, 概論 編, 2003.

3）鍋谷雅司, 水田富久, 稲垣太浩, 酒井運雄, 竹山智英, 太 田秀樹 : 長期供用後の地盤調查と挙動解析による軟弱地盤 上の道路盛土の性能評価, 第39回地盤工学研究発表会, pp.1327-1328, 2004.

4) 金子俊一朗, 大立目克明, 服部隆行, 工藤富士樹 : 厚い軟 弱地盤上に計画された低盛土道路における一変形解析例, 一理学的, 工学的情報の相互補完による実務設計の制度向 上を目指して一, 第46回地盤工学シンポジウム, pp.95-98, 2001.

5) 藤山哲雄, 稲垣太浩, 竜田尚希, 石黒健 : 軟弱地盤上の道 路盛土の性能設計検討事例（その2）長期変形挙動の再現 と今後の予測, 土木学会第57回年次学術講演会, pp.987-988, 2002.

6) 西村伸一, 藤井弘章, 松本寛展 : 変形および間隙水圧の計 測結果を利用した軟弱地盤の圧密挙動予測, 第 35 回地盤 
工学研究発表会, pp.1305-1306, 2000.

7) 竜田尚希, 稲垣太浩, 三嶋信雄, 藤山哲雄, 石黒健, 太田 秀樹 : 軟弱地盤上の道路盛土の供用後長期変形挙動予測と 性能設計一の応用, 土木学会論文集, No.743/III-64, pp.173-187, 2003.

8) 稲垣太浩, 三嶋信雄, 武部篤治, 藤山哲雄, 石黒健, 太田 秀樹: 軟弱地盤上の道路盛土に対する性能設計の試み, 土 木学会論文集，No.771/III-68，pp.91-110， 2004.

9) (財) 高速道路技術センター: 北陸自動車道 上越地区軟弱 地盤対策（EPS 工法）技術検討報告書, 1998 .

10) 川井田実, 森井慶行, 堀越研一, 飯塚敦, 太田秀樹 : 道路 盛土の除去およびEPS 置換に伴う軟弱地盤の挙動解析, 土 木学会論文集, No. 645/III-50, pp.209-221, 2000.

11) 今吉英明, 川井田実, 菅原秀明, 若林憲男 : 軟弱地盤の長 期沈下対策としての橋台裏込め軽量化工事，第 32 回地盤 工学研究発表会, pp.2601-2602, 1997.

12) 豊里栄吉, 滝沢芳則, 徳嵩秀晴 : 北陸道における橋台背面 部盛土の沈下対策（EPS 工法)，基礎工，6月号，pp.59-64， 2003.

13）北陸自動車道上越地区軟弱地盤対策工事（EPS 工法）に関 する技術論文募集，土と基礎，Vol. 45, No. 10, p.41-42, 1997.

14) 松山雅彦, 堀越研一, 石井裕泰, 稲垣太浩, 福島勇治, 緒 方健治 : EPS 置換を実施した軟弱粘土地盤上の橋台挙動の 解析的検討, 第 38 回地盤工学研究発表会, pp.1363-1364, 2003.

15) 川井俊介, 堀越研一, 稲垣太浩, 長尾和之, 三嶋信雄, 太 田秀樹 : 軟弱粘土地盤上の橋台の荷重軽減対策時期に関す る解析的検討, 第 39 回地盤工学研究発表会, pp.1341-1342, 2004.

16) Iizuka, A. and Ohta, H.:A determination procedure of input parameters in elasto-viscoplastic finite element analysis, Soils and Foundations, Vol.2, No.3, pp.71-87, 1987.

17) 地盤工学会 : 地盤工学・基礎理論シリーズ 1 地盤の変形 解析一基礎理論から応用まで一, pp.71，2002.

18）太田秀樹, 石井勇, 菅井一嘉, 飯塚敦 : 軟弱地盤上に施工 された高速道路試験盛土による変形とその数值シミュー
ション, 地盤工学における逆解析の適用と施工管理に関す るシンポジウム発表論文集, pp.123-132，1997.

19) Sekiguchi, H. and Ohta, H.: Induced anisotropy and time dependency in clays, Specialty Session 9, Proc. 9th Int. Conf. Soil Mechanics and Foundation Engineering, Tokyo, pp.229-239, 1977.

20) Massarsch, K. R. : Lateral Earth pressure in normally consolidated clay, Design Parameters in Geotechnical Engineering, Proc.7th Eur. Conf. Soil Mechanics and Foundation Engineering, Vol.2, pp.245-249, 1979.

21) Alpan, I.: The Empirical evaluation of the coefficient $K_{o}, K_{o r}$, Soils and Foundations, Vol.7, No.1, pp.31-40, 1967.

22） 発泡スチロール土木工法開発機構 : 発泡スチロール土木工 法技術資料 設計マニュアル第2 版, 1993.4 .

23）三嶋信雄，益村公人：FCB 工法 : 気泡混合軽量土を用いた 軽量盛土工法, 理工図書, p.47.

24) 川井俊介, 堀越研一, 稲垣太浩, 長尾和之, 三嶋信雄, 太 田秀樹 : 既設橋台荷重軽減対策としての気泡混合軽量土の 有効性に関する解析的検討, 土木学会第 59 回年次学術講 演会, pp.575-576, 2004.

25）東海興業・竹内建設共同企業体他 : 平成 11 年度高知自動 車道北原東工事軽量盛土工設計報告書， 2000 .

26) 山内豊聡, 浜田英治: 軽量盛土材としての気泡セメントの 力学特性と降伏規準に関寸る一考察, 土木学会論文集, 第 406 号/III-11, pp.283-290, 1989.

27) 星野克之, 横田聖哉, 小林一, 三嶋信雄 : 気泡混合軽量土 の材料特性, 第 30 回土質工学研究発表会, pp.2522-2523, 1995.

28) 日本道路公団新潟建設局他: 北陸自動車道 五貫野高架橋 対策工設計＼cjkstart対策工の経緯，p.63, 1983.

29) 高橋朋和, 川井田実, 土谷和博, 新井新一 : 高速道路にお ける建設費と管理費を考慮した軟弱地盤対策の事後評価, 土木学会論文集, No.693/ VI-53, pp.47-59， 2001.

(2005. 8.5 受付)

\section{ANALYTICAL STUDIES ON COST EFFECTIVE COUNTERMEASURES AGAINST DISPLACEMENT OF PILED BRIDGE ABUTMENT ON SOFT GROUND}

\section{Shunsuke KAWAI, Motohiro INAGAKI, Kenichi HORIKOSHI, Hiroshi ITAKIYO, Nobuo MISHIMA and Hideki Ohta}

This paper presents analytical studies on effective countermeasures against actual piled bridge abutment constructed on thick soft clay ground. After 13 years from the construction, unloading of embankment with the use of EPS (Expanded Poly-Styrol) was unavoidable to prevent further damage to surroundings. The effects of unloading timing was varied in the first stage of the analyses, then the applicability of FCB was studied by varying the unloading timing and area. Based on the assumed scenario of each countermeasure, effective countermeasures in terms of cost performance were discussed. 